REVISTA DE DERECHO UNED, NÚM. 22, 2018

\title{
LA RESPONSABILIDAD DIRECTA CON LOS BIENES GANANCIALES POR LAS DEUDAS DE NATURALEZA EXTRACONTRACTUAL INDIVIDUALMENTE CONTRAIIDAS
}

\section{THE DIRECT RESPONSIBILITY WITH THE COMMUNITY PROPERTY FOR THE DEBTS OF NON-CONTRACTUAL NATURE INDIVIDUALLY CONTRACTED}

\author{
Alberto Fabar Carnero \\ Abogado. Doctorando del Programa \\ de Doctorado en Derecho y Ciencias Sociales. \\ Universidad Nacional de Educación a Distancia (UNED) ${ }^{1}$
}

\begin{abstract}
Resumen: Las obligaciones extracontractuales contraídas por un cónyuge casado en régimen de gananciales, entendida esa noción en su acepción más expansiva y que comprende, así, a todas aquellas que no provienen de una previa relación contractual entre cónyuges y terceros, que sean formalmente subsumibles dentro del ámbito material prefigurado en el art. 1366 CC tendrán carácter ganancial y, por lo tanto, comprometerán directamente frente a los acreedores de la sociedad la masa común, sin que, en este sentido, a la conducta dolosa o gravemente culposa del cónyuge deudor, a los efectos de obviar resultados incongruentes o ilógicos, no obstante la literalidad de la norma, cuya exégesis correctora se propugna, se le pueda conferir virtualidad para excluir la afección social, reconduciéndose, en consecuencia, la operatividad de la mencionada excepción legal a la órbita interna. Por otra parte, la responsabilidad civil derivada de ilícitos
\end{abstract}

${ }^{1}$ Programa de Doctorado en Derecho y Ciencias Sociales. Equipo 3, Derecho civil y trabajo social. Línea 7, Derecho civil. Escuela Internacional de Doctorado de la UNED (EIDUNED). Universidad Nacional de Educación a Distancia (UNED).

(c) UNED. Revista de Derecho UNED, núm. 22, 2018 
penales perpetrados por un cónyuge en alguna de las actuaciones unilaterales comprendidas en la disposición analizada, en consonancia con esa proyección de la excepción exclusivamente en la relación intraconyugal, conformará un débito ganancial que vinculará ad extra el caudal del consorcio. En relación con las obligaciones tributarias imputables a un cónyuge, su incardinación en el régimen del art. 1366 es discutible y, de este modo, si las mismas están asociadas a la actividad profesional o comercial del deudor o a la titularidad de bienes o derechos privativos de este, habrán de ser consideradas deudas gananciales ex arts. $1365.2 .^{\circ}$ CC y 6 y ss. CCo.

Abstract: The non-contractual obligations contracted by a married spouse in community property regime, understood this concept in its most expansive meaning and that includes, so, all those that do not come from a previous contractual relationship between spouses and third parts, that are formally subsumable within the material ambit prefigured in the art. $1366 \mathrm{CC}$ they will have common character and, therefore, will compromise directly against to creditors of the society the common mass, without, in this sense, to the fraudulent or seriously culpable conduct of the debtor spouse, to the effects of obviating inconsistent or illogical results, however the literality of the norm, whose corrective exegesis is advocated, can confer you virtuality to exclude the social responsibility, redirecting, consequently, the operability of the mentioned legal exception to the internal orbit. On the other hand, the civil liability derived from criminal offences perpetrated by a spouse in any of the unilateral actions included in the analyzed disposition, in line with this projection of the exception exclusively in the relationship between spouses, will form a common debt that will link externally the flow of the consortium. In relation to the tax liabilities attributed to a spouse, their integration in the regime of the art. 1366 is debatable and, in this way, if the same they are associated with the professional or commercial activity of the debtor or with the ownership of goods or exclusive rights of this one will have to be considered common debts according to art. 1365.2. ${ }^{\circ} \mathrm{CC}$ y 6 and following CCo.

Palabras clave: Sociedad de gananciales, obligaciones extracontractuales, responsabilidad civil, dolo, culpa grave

Keywords: Community of property, non-contractual obligations, civil liability, malice, serious negligence.

Recepción original: 10/12/2017

Aceptación original: 12/01/2018 
Sumario: I. Introducción. II. El débito extracontractual en el régimen ganancial original del CC de 1889. III. El concepto de obligaciones extracontractuales del art. 1366 CC. III.A. La inclusión de las deudas indemnizatorias derivadas de ilícito penal. III.B. El controvertido encaje de los débitos tributarios en la disciplina del art. 1366 CC. III.C. El régimen de responsabilidad por obligaciones extracontractuales asumidas por un cónyuge en algunos sistemas de comunidad del Derecho comparado. IV. La actuación conyugal separada contemplada en el art. 1366 CC. V. El juego del dolo o la culpa grave del cónyuge deudor exclusivamente en la relación interna o cargo. VI. Conclusión. VII. Bibliografía

\section{INTRODUCCIÓN}

Aunque el art. $1366 \mathrm{CC}^{2}$, cuyo antecedente normativo inmediato es el art. 1410.2 y 3 CC 1889 , al que luego nos referiremos, prima facie, semeja unificar las nociones de deuda ganancial y carga definitiva de la comunidad en el supuesto de obligaciones extracontractuales contraídas individualmente por un cónyuge dentro del marco comprendido en aquella norma, esa pretendida asimilación conceptual, contraria a la estructuración dicotómica del pasivo ganancial tras la reforma de 1981, no es perfecta, como parece dimanar del tenor literal de la disposición, en tanto que, en nuestra opinión, la excepción plasmada en el precepto in fine opera únicamente en la relación interna, en línea, por lo demás, con la idea de que la afección externa consorcial por la actuación autónoma de los cónyuges, a efectos de la tutela de los intereses de terceros, ha de sujetarse a criterios formales, difícilmente compatibles con la ponderación de la concurrencia de dolo o culpa grave en la conducta del cónyuge deudor ${ }^{3}$.

En la hipótesis de obligaciones extracontractuales contraídas por ambos cónyuges no resulta de aplicación la regla del art. 1366 CC, que alude taxativamente a las obligaciones extracontractuales de un cónyuge, en singular, de donde se deriva que en el caso de actuación conjunta conyugal el débito extracontractual tendrá indefectiblemen-

\footnotetext{
${ }^{2}$ Dispone este precepto que «las obligaciones extracontractuales de un cónyuge, consecuencia de su actuación en beneficio de la sociedad conyugal o en el ámbito de la administración de los bienes, serán de la responsabilidad y cargo de aquélla, salvo si fuesen debidas a dolo o culpa grave del cónyuge deudor».

${ }^{3}$ Sobre este extremo, cfr. FABAR CARNERO, Alberto, "Aproximación al régimen de responsabilidad externa en la sociedad de gananciales», RDUNED, n. ${ }^{\circ} 19,2016$, pág. 681 .
} 
te naturaleza ganancial ex art. $1367 \mathrm{CC}$, con la consecuencia inherente del compromiso indistinto ad extra de la totalidad de las tres masas patrimoniales implicadas, es decir, la ganancial y el haber privativo de cada uno de los cónyuges ${ }^{4}$.

La catalogación de la deuda extracontractual como ganancial va a exigir, según se analizará a continuación, que la actuación del cónyuge que la produce, cuando menos aparentemente, esté orientada al beneficio de la sociedad conyugal o se verifique en el ámbito de la administración, ordinaria o extraordinaria, de bienes privativos o comunes. Contrariamente, si no se acredita por el acreedor la circunstancia referida, la obligación extracontractual en cuestión tendrá naturaleza privativa y vinculará directamente los bienes propios del cónyuge deudor y subsidiariamente la masa común, de conformidad con lo establecido en el art. $1373 \mathrm{CC}^{5}$.

El presente artículo se inicia con un análisis del derogado art. 1410.3 CC 1889, en la medida en que es el precedente normativo inmediato del vigente art. 1366 CC. Igualmente, siguiendo una secuencia lógica, examinamos el concepto de obligaciones extracontractuales y, prescindiendo de referirnos específicamente a la responsabilidad civil extracontractual, dada su obvia subsunción en aquella noción legal, nos centramos en dos supuestos cuya incardinación en el marco del mencionado precepto suscita controversia, cuales son los debitos contraídos por un cónyuge por responsabilidad civil ex delicto y los dimanantes de obligaciones fiscales imputables a título individual a los cónyuges. Asimismo, se hace una referencia al estado de la cuestión en los regímenes de comunidad conyugal de los ordenamien-

${ }^{4}$ Luis Felipe RAGEL SÁNCHEZ (en El Régimen de Gananciales, Aranzadi, Cizur Menor, 2017, pág. 473) alude a que la obligación extracontractual causada por la acción u omisión de ambos cónyuges (o por un hijo común sujeto a la guarda de aquellos) es una deuda ganancial conforme al art. 1367 CC, siendo necesario a tal efecto que la sentencia declare la existencia de una obligación extracontractual de los dos cónyuges. Igualmente, María del Rosario MARTÍN BRICEÑO [en «La responsabilidad de los bienes gananciales por las obligaciones extracontractuales de un cónyuge (1)», LA LEY Derecho de familia, n. ${ }^{\circ} 8$, 2015, pág. 3 de la versión digital obrante en laleydigital360 (LA LEY 5936/2015)] circunscribe el juego del precepto al supuesto de las obligaciones extracontractuales asumidas por uno de los cónyuges y no por ambos conjuntamente.

${ }^{5}$ Para Javier BARCELÓ DOMÉNECH (en Responsabilidad de los bienes gananciales por las obligaciones extracontractuales de un cónyuge, Tirant lo Blanch, Valencia, 2000, pág. 32), el legislador, en vez de crear un precepto específico para las deudas extracontractuales, podría haber definido en los arts. 1362 y 1365 todos los débitos que constituyen el pasivo social, sirviendo la norma del art. 1366 para excluir ciertas deudas de ese pasivo, como serían las dimanantes de delito, que se considerarían privativas. 
tos francés, portugués e italiano. A continuación, aludimos en este estudio a la concreta actuación conyugal individual que genera la deuda extracontractual consorcial, para culminar el trabajo con el aspecto crucial del alcance de la excepción legal del dolo o la culpa grave del cónyuge deudor y la defensa de su reconducción a la esfera exclusivamente interna.

\section{EL DÉBITO EXTRACONTRACTUAL EN EL RÉGIMEN GANANCIAL ORIGINAL DEL CC DE 1889}

El art. 1410.3 CC $1889^{6}$, el cual, a su vez, concordaba, en esencia, con el art. 1331.3 del Proyecto de CC de 1851, venía a consagrar explícitamente una responsabilidad meramente subsidiaria y provisional del acervo común por los débitos antematrimoniales producidos por cualquiera de los cónyuges y, asimismo, por multas y condenas impuestas a aquellos constante la sociedad conyugal, deudas estas que habían de catalogarse, no como consorciales, sino como personales o privativas del deudor. En cualquier caso, conforme establecía el indicado precepto, para una eventual agresión de la masa común por los acreedores por las deudas extracontractuales separadamente asumidas se requería que estuvieran cubiertas las atenciones previstas en el art. 1408 CC y que el cónyuge deudor careciera de capital propio o este fuera insuficiente, extremos que tendrían que ser adverados judicialmente por el acreedor que pretendiera realizar bienes ganancia$\mathrm{les}^{7}$, deduciéndose al tiempo de la liquidación de la comunidad ganancial, de manera consecuente con la no conceptuación como carga de la sociedad de las argüidas obligaciones ${ }^{8}$, lo satisfecho a costa del

${ }^{6}$ En concreto, el art. 1410.3 ex CC 1889 determinaba que «sin embargo, el pago de las deudas contraidas por el marido o la mujer con anterioridad al matrimonio, y el de las multas y condenas que se le impongan (que, según el párrafo segundo del precepto, no integraban una carga de la comunidad), podrá repetirse contra los gananciales después de cubiertas las atenciones que enumera el artículo 1.408, si el cónyuge deudor no tuviese capital propio o fuera insuficiente; pero al tiempo de liquidarse la sociedad se le cargará lo satisfecho por los conceptos expresados».

${ }^{7}$ Entre otros, entendía que la carga de la prueba correspondía al acreedor Federico PUIG PEÑA, Tratado de Derecho Civil español, T. II (Derecho de familia), Vol. I (Teoría general del matrimonio), Ed. Revista de Derecho Privado, Madrid, 1947, pág. 310.

${ }^{8}$ La no consideración de carga del consorcio de las multas y condenas pecuniarias impuestas a los cónyuges se justificaba por Calixto VALVERDE Y VALVERDE [en Tratado de Derecho civil español, T. IV, Parte especial (Derecho de familia), 2. ${ }^{\text {a }}$ ed., Talleres Tipográficos Cuesta, Valladolid, 1921, pág. 362] atendiendo a que se trataba de un caso de responsabilidad personal, que no podía afectar al interés común de la sociedad. 
acervo social por esos débitos personales del capital correspondiente al deudor 9 .

En relación con la carga de la prueba de la concurrencia de los dos requisitos que permitían la afección provisional del consorcio por los débitos privativos extracontractuales en la disciplina primigenia del CC, teniendo en cuenta la dificultad de que los acreedores conocieran cuáles de las atenciones del art. 1408 estaban o no cubiertas, se preconizaba por algún autor una inversión de la reiterada carga de la prueba, de forma que el acreedor hubiera de justificar solamente la carencia de bienes propios en el cónyuge deudor, siendo el marido o la mujer quienes debían demostrar que estaban pendientes de cumplimiento aquellas atenciones ${ }^{10}$.

Por lo tanto, de conformidad con el tenor del derogado art. 1410.3 $\mathrm{CC}$, para hacer efectiva la responsabilidad externa, provisional y supletoria del caudal ganancial por obligaciones extracontractuales individualmente generadas no resultaba necesaria la disolución y liquidación de la comunidad, a los efectos de que el cónyuge deudor abonara con su mitad ganancial la deuda privativa por él contraída, bastando, en este sentido, que el acreedor de aquel probara la existencia de bienes sobrantes una vez cubiertas las atenciones del art. 1408 y la ausencia o insuficiencia del haber propio del deudor.

LACRUZ, que extendía analógicamente el régimen del art. 1410 a cualesquiera deudas privativas asumidas por los cónyuges, afirmaba

${ }^{9}$ Comentaba Alfonso DE COSSÍO Y CORRAL (en La sociedad de gananciales, en Tratado práctico y crítico de Derecho civil, T. 50, Vol. I, Instituto Nacional de Estudios Jurídicos, Madrid, 1963, pág. 98) que el derecho a perseguir bienes gananciales en los supuestos concretados en el art. 1410 CC precisaba seguir un procedimiento declarativo, en el que tendrían que ser demandados ambos cónyuges para cumplimentar lo dispuesto en el art. 144 del Reglamento Hipotecario, acreditando en la causa la concurrencia de los dos requisitos exigidos, sin lo cual no cabría la anotación de la demanda o traba sobre bienes comunes, ni, por lo demás, seguirse ejecución contra estos.

Como ponía de manifiesto Felipe Clemente DE DIEGO (en Instituciones de Derecho Civil Español, T. II, Imprenta de Juan Pueyo, Madrid, 1930, pág. 454), si las deudas importaban más que el activo sería ilusorio desquitar lo pagado al cónyuge deudor al liquidarse la sociedad. Vid. también en este sentido CASTÁN TOBEÑAS, José, Derecho Civil Español, Común y Foral, T. V (Derecho de familia), Vol. I (Relaciones conyugales), 9. ${ }^{a}$ ed. (revisada y puesta al día por GARCÍA CANTERO y CASTÁN VÁZQUEZ), Reus, Madrid, 1976, pág. 378, y SÁNCHEZ ROMÁN, Felipe, Estudios de Derecho Civil según los principios, los precedentes y cuerpos legales del antiguo Derecho de Castilla, las leyes civiles generales, las especialidades de las legislaciones forales, la jurisprudencia del Tribunal Supremo de Justicia y el Código Civil é historia general de la legislación española, T. V, 2. ${ }^{\text {a }}$ ed., Vol. I, Derecho de familia, Establecimiento Tipográfico «Sucesores de Rivadeneyra», Madrid, 1898, págs. 848-849.

${ }^{10}$ REYES MONTERREAL, José María, El régimen legal de gananciales, Gráficas Menor, Madrid, 1962, pág. 249. 
que cuando ese artículo hablaba de multas y condenas pecuniarias pretendía incluir las responsabilidades dimanantes de la culpa extracontractual, concluyendo que con el término contraídas del art. $1408.1 .^{\circ}$ se indicaban, exclusivamente, las obligaciones contractuales, sin perjuicio de que el caudal común respondiera por las restantes en el modo previsto en el art. $1410^{11}$.

El ámbito de la norma de responsabilidad provisional contenida en el art. 1410.3 CC era, objetiva y subjetivamente, más amplio que el propuesto en el art. 1331.3 del Proyecto de 1851 (y en el art. 1436.3 del Anteproyecto del CC, coincidente sustancialmente con el anterior), en la medida en que estas dos últimas normas, por una parte, no exigían que estuvieran cubiertas las atenciones familiares, requiriéndose tan solo la excusión del capital propio del marido, y, por otra, aludían, únicamente, a las multas y condenas impuestas al marido y no a la mujer.

La generalidad de la expresión multas y condenas pecuniarias del art. 1410, en opinión de MANRESA, permitía salir de la esfera de acción del CP y aplicar la norma a toda condena pecuniaria impuesta a uno solo de los cónyuges por actos personales del mismo o por responsabilidad que le sean imputables o peculiares ${ }^{12}$.

La noción de multas la referían DÍEZ-PICAZO y GULLÓN a las sanciones pecuniarias de cualquier tipo (civiles, administrativas...), en tanto que el concepto de condenas pecuniarias, a su juicio, no cabía aplicarlo a toda clase de condena, por cuanto que, una vez dictada sentencia condenatoria, por esa vía cualesquiera obligaciones contraídas por los cónyuges estarían sujetas al régimen del art. 1410, no siendo este resultado consecuente con el resto del sistema ${ }^{13}$.

${ }^{11}$ LACRUZ BERDEJO, José Luis, en LACRUZ y ALBALADEJO, Derecho de familia. El matrimonio y su economía, Tratado teórico-práctico de Derecho Civil, T. IV, Vol. 1. ${ }^{\circ}$, Librería Bosch, Barcelona, 1963, págs. 521-523. Entendía LACRUZ que cuando la culpa en que hubiera incurrido el marido en la gestión de intereses comunes fuera compartida de alguna forma por la mujer sería admisible la ejecución dirigida directamente contra los bienes gananciales, sin necesidad de hacer excusión en los del marido y sin que la mujer pudiera reclamar nada.

12 MANRESA Y NAVARRO, José María, "Artículo 1410», Comentarios al Código Civil Español, T. IX, 5. a ed. (revisada por CASTÁN VÁZQUEZ), Instituto Editorial Reus, Madrid, 1950, pág. 625.

${ }^{13}$ DÍEZ-PICAZO Y PONCE DE LEÓN, Luis, y GULLÓN BALLESTEROS, Antonio, Sistema de Derecho Civil, Vol. IV (Derecho de familia. Derecho de sucesiones), Tecnos, Madrid, 1978, pág. 214. Restringían estos autores (ibíd., págs. 214-215) el alcance de la expresión condenas pecuniarias a las obligaciones que no estuvieran originadas por una relación jurídica negocialmente establecida (por ej., responsabilidad extracontractual). Por su parte, Q. MUCIUS SCAEVOLA [en Código Civil concordado y comentado extensamente, T. XXII (Artículos 1.392 á 1.444),

(C) UNED. Revista de Derecho UNED, núm. 22, 2018 
Como luego se dirá, el precedente normativo que representa el antiguo art. 1410.3 CC, el cual, según se ha reseñado, establecía, de darse acumuladamente las dos premisas recogidas en la disposición, una responsabilidad puramente provisional con la masa ganancial por cualesquiera deudas de naturaleza extracontractual generadas de forma disyunta por los cónyuges, no excluida, por consiguiente, por la conducta dolosa o gravemente culposa del cónyuge deudor, es un aspecto más que, entre otros que se indicarán, ex art. 3.1 CC, juega a favor de la exégesis correctora que sostenemos acerca de que la excepción legal del actual art. 1366 (dolo o culpa grave del cónyuge deudor) debe proyectarse limitadamente sobre la relación ad intra y no operar en la esfera externa.

\section{EL CONCEPTO DE OBLIGACIONES EXTRACONTRACTUALES DEL ART. 1366 CC}

Delimitar la noción de obligaciones extracontractuales que recoge el art. 1366, inédita en el Código, es una cuestión controvertida en la doctrina científica, por la vaguedad de la expresada mención legal, que cabe referir, si se parte de una exégesis expansiva o literal, a todas aquellas obligaciones que no proceden de un contrato, atendiendo a la acepción del vocablo extracontractual que proporciona la $\mathrm{RAE}^{14}$, o si,

Imprenta de P. Apalategui, Madrid, 1905, págs. 307-308], que asimilaba los términos multa y condena pecuniaria, englobaba en el art. 1410 las condenas impuestas como responsabilidad en los órdenes penal y civil, atendiendo ese artículo a la imputabilidad de todo acto ilícito, y comprendiendo en el precepto todas las condenas que traen su causa de un motivo civil cualquiera de obligar, de manera que la expresión condenas pecuniarias abarca tanto una imposición de costas como la declaración de que es debida una cantidad. También COSSÍO, op cit., págs. 99-100, afirmaba que no ofrecía duda alguna que las multas derivadas del delito y las condenas pecuniarias impuestas en causa criminal se hallaban incluidas en la norma, así como las producidas en procedimiento gubernativo sancionador de faltas, deviniendo irrelevante la jurisdicción sancionadora, siempre que se trate de un procedimiento propiamente penal. Sin embargo, este autor no incardinaba las condenas impuestas en procesos civiles en el ámbito de la disposición examinada, salvo en los supuestos de condena en costas como sanción de la temeridad y el de responsabilidades civiles derivadas de delito o falta pero exigidas por vía civil.

${ }^{14}$ Para LACRUZ BERDEJO (en LACRUZ et al., Elementos de Derecho Civil, IV, Derecho de familia, Vol. I, 3. ${ }^{a}$ ed., José María Bosch Editor, Barcelona, 1990, págs. 428-429), el contexto normativo y la referencia en el artículo, no solo a la actuación en el ámbito de la administración de los bienes, sino asimismo en beneficio de la sociedad conyugal, propician el mantenimiento de la tesis amplia. Se muestran también partidarios de la concepción amplia de la expresión obligaciones extracontractuales DÍEZ-PICAZO y GULLÓN [en Sistema de Derecho Civil, Vol. IV (T. I), Derecho de familia, 11. ${ }^{a}$ ed., Tecnos, Madrid, 2013, pág. 178], en cuya opinión, si bien las obligaciones extracontractuales son esencialmente las originadas por culpa o 
por el contrario, se opta por una perspectiva más restrictiva y próxima al supuesto paradigmático de esta clase de obligaciones, a la responsabilidad civil extracontractual de los arts. 1902 y ss. CC $^{15}$.

Sobre este extremo, colige BELLO JANEIRO que resulta más seguro y menos problemático restringir la operatividad del art. 1366 CC a partir de las limitaciones contempladas en el mismo (fundamentalmente, dolo y culpa grave) y no en función del ámbito al que alude con la desafortunada expresión legal ${ }^{16}$.

Consideramos que cuando el precepto utiliza la expresión obligaciones extracontractuales está aludiendo a aquellas obligaciones que no traen su causa, en sentido estricto, de una relación contractual previa entre las partes, por lo que, teniendo en cuenta la enumeración de las fuentes de las obligaciones del art. 1089 CC, han de residenciarse en el concepto legal las obligaciones nacidas de la ley, de los cuasicontratos, de la responsabilidad civil extracontractual y, por lo que respecta a la esfera externa, igualmente, las nacidas de la comisión de ilícitos penales.

negligencia que ocasiona daño a terceros (art. 1902 CC), comprenden en general a todas aquellas que no tengan su fundamento en una obligación convencionalmente asumida; RAGEL SÁNCHEZ (en El Régimen de Gananciales, cit., pág. 467), que califica como obligación extracontractual toda la que no derive directamente de un contrato; BARCELÓ DOMÉNECH (en Responsabilidad de los bienes gananciales por las obligaciones extracontractuales de un cónyuge, cit., págs. 64-65); Yolanda B. BUSTOS MORENO (en Las deudas gananciales y sus reintegros, Dykinson, Madrid, 2003, pág. 319) y Luis MARTÍNEZ VÁZQUEZ DE CASTRO (en Responsabilidad patrimonial de la sociedad de gananciales, Civitas, Madrid, 1995, págs. 45-46).

${ }^{15}$ Entre los defensores de una visión más limitada del concepto, podemos citar a Joaquín José RAMS ALBESA (en La sociedad de gananciales, Tecnos, Madrid, 1992, pág. 352), autor que restringe el ámbito de la norma a las acciones $\mathrm{u}$ omisiones, de naturaleza no penal, que producen daño a un tercero, siempre que este no derive del dolo o culpa grave del cónyuge deudor; Ramón ABELLÓ MARGALEF (en «Notas sobre las cargas y obligaciones de la sociedad de gananciales», $R D P, \mathrm{n} .{ }^{\circ} 66,1982$, pág. 811), quien propone que siempre ha de tratarse de la responsabilidad que prevé el art. 1902 CC y no de la responsabilidad civil ex delicto, aconteciendo el resultado dañoso por una conducta ilícita civil; Manuel PEÑA BERNALDO DE QUIRÓs (en «Art. 1.366», en PAZ-ARES et al. (Dirs.), Comentario del Código Civil, T. II, Ministerio de Justicia, Madrid, 1991, pág. 698), que excluye del régimen del art. 1366 a las obligaciones ex lege, entre ellas, las fiscales o cuasicontractuales contraídas por un cónyuge; y Manuel Ángel RUEDA PÉREZ y José María RUEDA PÉREZ (en «Notas sobre la nueva regulación de las cargas y obligaciones de la sociedad de gananciales tras la reforma del Código Civil de 13 de mayo de 1981 », RDP , n. ${ }^{\circ} 66,1982$, pág. 569), los cuales vienen a concluir que no todas las obligaciones extracontractuales están incluidas en la norma del art. 1366.

${ }^{16}$ BELLO JANEIRO, Domingo, La defensa frente a tercero de los intereses del cónyuge en la sociedad de gananciales, José María Bosch Editor, Barcelona, 1993, pág. 408. Este autor sitúa fuera de la disciplina del art. 1366 los supuestos de responsabilidad civil por delito. 


\section{III.A. La inclusión de las deudas indemnizatorias derivadas de ilícito penal}

Si bien el régimen legal de la responsabilidad civil derivada de ilícitos penales y civiles se disciplina de forma separada en el CP y en el $\mathrm{CC}$, respectivamente, de conformidad con lo prescrito en los arts. 1092 y 1093 CC, la existencia de esa regulación dual es objeto de crítica en tanto que la responsabilidad civil a la que se refieren estos dos preceptos es la misma ${ }^{17}$.

La postura favorable a la exclusión de los débitos indemnizatorios ex delicto contraídos individualmente por un cónyuge del marco del art. 1366, en la doble perspectiva del cargo y de la afección externa, y que, en consecuencia, se inclina por la naturaleza privativa de esas deudas, de la que discrepamos, se fundamenta, sustancialmente, en que la responsabilidad penal presupone la concurrencia de una conducta dolosa o gravemente culposa en el autor del delito, de manera que, propugnándose la operatividad de la excepción legal contenida in fine en la disposición estudiada también en la relación ad extra, derivaría como conclusión la expulsión liminar de la responsabilidad civil ex delicto impuesta a un cónyuge del espectro de posibles deudas extracontractuales consorciales ${ }^{18}$.

${ }^{17}$ YZQUIERDO TOLSADA, Mariano, «El perturbador artículo 1.092 del Código Civil: cien años de errores», en Centenario del Código Civil (1889-1989), T. II, Ed. Centro de Estudios Ramón Areces, Madrid, 1990, pág. 2111.

${ }^{18} \mathrm{La}$ despenalización de las conductas ocasionadas por imprudencia leve se justifica en el Preámbulo de la Ley Orgánica 1/2015, de 30 de marzo, por la que se modifica la Ley Orgánica 10/1995, de 23 de noviembre, del Código Penal, indicando que «se recoge así una modulación de la imprudencia delictiva entre grave y menos grave, lo que dará lugar a una mejor graduación de la responsabilidad penal en función de la conducta merecedora de reproche, pero al mismo tiempo permitirá reconocer supuestos de imprudencia leve que deben quedar fuera del Código Penal. No toda actuación culposa de la que se deriva un resultado dañoso debe dar lugar a responsabilidad penal, sino que el principio de intervención mínima y la consideración del sistema punitivo como última ratio, determinan que en la esfera penal deban incardinarse exclusivamente los supuestos graves de imprudencia, reconduciendo otro tipo de conductas culposas a la vía civil, en su modalidad de responsabilidad extracontractual o aquiliana de los artículos 1902 y siguientes del Código Civil, a la que habrá de acudir quien pretenda exigir responsabilidad por culpa de tal entidad» (cfr. BOE n. ${ }^{\circ} 77$, de 31 de marzo de 2015, pág. 27084).

Se inclina por la responsabilidad directa del patrimonio ganancial por las consecuencias económicas del delito penal perpetrado por un cónyuge al amparo del art. 1366 Vicente TORRALBA SORIANO, "Art. 1.366», en AMORÓS GUARDIOLA et al., Comentarios a las reformas del Derecho de familia, Vol. II, Tecnos, Madrid, 1984, pág. 1697. Cfr., en este sentido, MARTÍNEZ VÁZQUEZ DE CASTRO, Responsabilidad patrimonial..., cit., pág. 48.

Mantienen una postura contraria a residenciar en el ámbito del art. 1366 la responsabilidad civil derivada del delito, entre otros autores, BARCELÓ DOMÉNECH 
En el caso de que ambos cónyuges sean condenados como coautores de un delito la eventual responsabilidad civil declarada en el fallo penal tendrá imperativamente la calificación de deuda consorcial y comprometerá directamente, indistinta o solidariamente, las masas privativas de los cónyuges condenados y la ganancial, mas no por aplicación del art. 1366, que contempla una actuación conyugal individual y no dual o autónoma consentida expresamente, sino en virtud del art. 1367, en relación con los arts. 1369 y 1911, CC, y 116.2 CP, no apreciándose, en fin, motivo alguno para restringir el ámbito del art. 1367 a los débitos contractuales.

La reconducción de la excepción legal del art. 1366 a la relación intraconyugal o cargo de la sociedad ganancial determinará que si la responsabilidad civil proveniente del delito individualmente perpetrado por un cónyuge (necesariamente con dolo o imprudencia grave o menos grave) se ha satisfecho sobre el patrimonio común, el cónyuge deudor habrá de reembolsar a la sociedad, en el momento de la liquidación, el importe actualizado de la cantidad satisfecha ex art. 1397.3. ${ }^{\circ} \mathrm{CC}$, configurándose el supuesto examinado como una hipótesis de responsabilidad simplemente provisional y directa de la masa social.

El TS, que carece de una doctrina consolidada en relación con la ganancialidad de la responsabilidad civil ex delicto, ha admitido, no obstante, que la misma puede englobarse en la categoría de las obligaciones extracontractuales, entendiendo la STS de 31 de marzo de 2004, resolución que, ante la acción de repetición ejercitada por una aseguradora, avaló el carácter privativo de un débito por responsabilidad civil dimanante de un delito de imprudencia temeraria con resultado de lesiones por el que había sido condenado un cónyuge y que expresamente asume que la excepción legal establecida en el art. 1366 in fine excluye el cargo y la responsabilidad ganancial, que aquel es un concepto amplio, en el cual se comprenden las obligaciones nacidas de la condena penal de carácter resarcitorio del daño ocasionado por el delito, o, dicho en otras palabras, la responsabilidad civil nacida del delito. Remarca el TS que constituye la única característica que identifica las obligaciones referidas en el art. 1366 su naturaleza extracontractual, por lo que «sería, por tanto, arbitrario dejar fuera a las

(en Responsabilidad de los bienes gananciales..., cit., pág. 80), DE LOS MOZOS Y DE LOS MOZOS [en "Artículo 1.366», en ALBALADEJO (Dir.), Comentarios al Código Civil y Compilaciones Forales, T. XVIII, Vol. 2. (Artículos 1.344 a 1.410 del Código Civil), Ed. Revista de Derecho Privado, Madrid, 1984, págs. 293-296), BELLO JANEIRO (en La defensa frente a tercero..., cit., págs. 408-409) y ABELLÓ MARGALEF (en «Notas sobre las cargas y obligaciones...», cit., pág. 811).

(C) UNED. Revista de Derecho UNED, núm. 22, 2018 
que tienen su fuente en la condena penal. No parece fundado que el daño que da origen a la responsabilidad civil aquiliana permitiese al cónyuge del autor beneficiarse de la excepción del art. 1.366, y no al cónyuge del condenado a resarcir en vía penal por razón de delito, es decir, por una actuación más grave» ${ }^{19}$.

Por su parte, la STS de 25 de septiembre de 1999, que examinaba una tercería de dominio planteada por la cónyuge de un condenado por delito respecto de diversos inmuebles embargados en la pieza de responsabilidad civil de la causa penal, adjudicados a la tercerista tras la liquidación social efectuada durante el curso de las actuaciones penales, después de entender que el otorgamiento de capitulaciones se había formalizado con el ánimo de detraer de la masa liquidable la mayor parte de los bienes comunes y negar la cualidad de tercero a la tercerista ex art. 1333, en relación con el art. 1317, CC, sostiene, en apoyo de la posible condición consorcial de las deudas indemnizatorias ex delicto contraídas por un cónyuge, que «conviene decir pronto que una cosa son las condenas pecuniarias por razón del principio de la personalidad de la pena, y otra, distinta, la responsabilidad civil inherente a los hechos tipificados como delictivos y respecto a estos no resulta extraña a la responsabilidad ganancial» ${ }^{20}$.

El hecho de que no exista un criterio plausible del TS en cuanto a la cualidad ganancial de las deudas indemnizatorias que traen su causa de los ilícitos penales, concepto en el que, evidentemente, atendiendo al principio de personalidad de la pena, no es factible comprender las eventuales multas que se impongan, y, por extensión, del ámbito de aplicabilidad de la excepción del art. 1366 CC, en tanto que la admisión

${ }^{19}$ STS de 31 de marzo de 2004 (Cendoj-ECLI:ES:TS:2004:2242).

${ }^{20}$ STS de 25 de septiembre de 1999 (Cendoj-ECLI:ES:TS:1999:5802).

Igualmente, la SAN, Sala de lo Contencioso-Administrativo, de 14 de marzo de 2011 (Cendoj-ECLI:ES:AN:2011:1496) atribuye la condición de débito ganancial a la responsabilidad civil derivada de dos delitos contra la Hacienda Pública (por los conceptos de IS e IVA) por los que fue condenado un cónyuge en su condición de administrador de una mercantil, cuyo abono fue exigido, de conformidad con lo dispuesto en la Disposición Adicional Décima ex LGT, por la vía administrativa de apremio, que se siguió sucesivamente contra el condenado y su excónyuge. Se rechaza en aquella sentencia la oponibilidad de la liquidación de la sociedad de gananciales, teniendo en cuenta el devengo de las deudas tributarias constante la comunidad, ex arts. 1317 y 1401 CC, y, reiterando el compromiso de los bienes gananciales que fueron adjudicados a la esposa, para concluir la ganancialidad de la deuda tributaria exigida en concepto de responsabilidad civil se aducen los arts. 1362.4. ${ }^{\mathrm{a}}$ y 1365 CC y 6,7 y 8 CCo, prescindiendo de invocar el art. 1366 a los efectos de determinar la afección ad extra de la sociedad legal por el débito (extracontractual) en cuestión e incurriendo en el error clásico de argüir un precepto que regula el pasivo ganancial interno cuando estamos en sede de responsabilidad externa. La resolución citada fue confirmada posteriormente por STS, Sala Tercera, de 26 de junio de 2013 (Cendoj-ECLI:ES:TS:2013:3644). 
del juego de esta en la relación ad extra supondría la no subsunción en el contorno del precepto señalado de la responsabilidad civil ex delicto, tiene su continuación en la fragmentada doctrina que se observa en las resoluciones de las Audiencias Provinciales, quizás decantada mayoritariamente por postular la privatividad de los citados débitos ${ }^{21}$.

\section{III.B. El controvertido encaje de los débitos tributarios en la disciplina del art. 1366 CC}

En principio, en la medida en que las deudas tributarias tienen naturaleza legal procedería insertar las mismas en la noción de obligaciones extracontractuales, considerada esta última en su sentido más amplio, si bien, atendiendo a la asimilación de aquellas a los débitos gananciales del art. $1365 \mathrm{CC}$ que se contempla en los arts. 106 Ley IRPF ${ }^{22}$, 48 LIRNR $^{23}$ y $34 \operatorname{LIP}^{24}$ y a la circunstancia de que usualmente esas deudas, singularmente por IRPF e IVA, surgen en el ámbito de la actividad profesional o comercial de cualquiera de los cónyuges, lo que conllevaría su condición consorcial ex art. $1365.2 .^{\circ} \mathrm{CC}$, en relación con los arts. 6 y ss. CCo, no se juzga imperativo encuadrar cualesquiera débitos tributarios contraídos por un cónyuge en el régimen del art. $1366^{25}$.

${ }^{21}$ Así, rechazan la cualidad ganancial de las deudas nacidas de la responsabilidad civil derivada de un ilícito penal, entre otras muchas, la SAP de A Coruña de 12 de diciembre de 2008 (Cendoj-ECLI:ES:APC:2008:3635), la SAP de Sevilla de 2 de febrero de 2000 (Cendoj-ECLI:ES:APSE:2000:405), la SAP de Cádiz de 3 de julio de 2009 (Cendoj-ECLI:ES:APCA:2009:938) y la SAP de Madrid de 25 de octubre de 2006 (Cendoj-ECLI:ES:APM:2006:17571). Por el contrario, admiten la posible condición consorcial de los débitos indemnizatorios ex delicto la SAP de Madrid de 14 de junio de 2004 (Cendoj-ECLI:ES:APM:2004:8802), el AAP de Las Palmas de Gran Canaria de 12 de marzo de 2010 (Cendoj-ECLI:ES:APGC:2010:332A) o la SAP de Guadalajara de 3 de marzo de 2010 (Cendoj-ECLI:ES:APGU:2010:47).

${ }^{22}$ Concretamente, el art. 106 ex Ley IRPF (Impuesto sobre la Renta de las Personas Físicas) declara que «las deudas tributarias y, en su caso, las sanciones tributarias, por el Impuesto sobre la Renta de las Personas Físicas tendrán la misma consideración que las referidas en el artículo 1365 del Código Civil y, en consecuencia, los bienes gananciales responderán directamente frente a la Hacienda Pública por estas deudas, contraídas por uno de los cónyuges, sin perjuicio de lo previsto en el apartado 6 del artículo 84 de esta ley para el caso de tributación conjunta».

${ }^{23}$ Cfr. art. 48 ex Ley del Impuesto sobre la Renta de no Residentes.

${ }^{24}$ Cfr. art. 34 ex Ley del Impuesto sobre el Patrimonio.

${ }^{25} \mathrm{La}$ conceptuación de la deuda tributaria como débito profesional o mercantil consorcial $e x$ arts. $1365.2{ }^{\circ} \mathrm{CC}$ y 6 y ss. CCo, en cuanto a IRPF e IVA, se establece, entre otras, en la SAP de Zamora de 22 de noviembre de 2016 (Cendoj-ECLI:ES:APZA:2016:379), SAP de Guadalajara de 30 de junio de 2004 (Cendoj-ECLI:ES:APGU:2004:277), SAP de Madrid de 16 de enero de 2009 (Cendoj-ECLI:ES:APM:2009:1730) y SAP de León de 16 de noviembre de 2011 (Cendoj-ECLI:ES:APLE:2011:1290).

(C) UNED. Revista de Derecho UNED, núm. 22, 2018 
La deuda tributaria ganancial, ex art. 58 de la Ley General Tributaria (LGT), está conformada por la cuota o cantidad a ingresar, intereses de demora y distintos recargos, debiendo excluirse las sanciones que se impongan al cónyuge deudor, las cuales, sin perjuicio de lo establecido en el art. 106 LIRPF, en atención a su naturaleza punitiva significadamente personal, son débitos privativos de aquel (al igual que si se da una eventual declaración de responsabilidad solidaria o subsidiaria que se extienda a las sanciones ex arts. 174 a 176, en relación con los arts. 182 y 42 y 43, LGT) y no comprometerán, en consecuencia, directamente el activo social frente a la Administración tributaria y se someterán a lo dispuesto en el art. $1373^{26}$.

En relación con las obligaciones fiscales, se ha afirmado que cabe la posibilidad de colegir que aquellas pueden residenciarse, no solo en el art. 1366, sino, asimismo, en otros preceptos reguladores del pasivo consorcial, todo ello sin prejuzgar las particulares normas sobre responsabilidad frente a la Hacienda Pública que establece la regulación fiscal $^{27}$.

Para ALGABA ROS, desde la óptica del acreedor, resulta más favorable subsumir las obligaciones fiscales en el marco del art. 1366, por tratarse de obligaciones legales que no tienen carácter contractual, facilitándose con ello la ejecución al clarificar el patrimonio sujeto a la responsabilidad externa ante esta tipología de débitos ${ }^{28}$.

Un supuesto usual de compromiso ad extra del haber común por obligaciones tributarias imputables a un cónyuge se refiere a la situación en la que aquel es administrador de una mercantil que contrae una deuda tributaria constante la comunidad ganancial y, previa declaración de fallido de la persona jurídica deudora principal y, en su caso, de los responsables solidarios, y la derivación de la acción administrativa, se le exige al citado cónyuge, dada la concurrencia del presupuesto de hecho previsto legalmente, la pertinente responsabilidad subsidiaria ex arts. 41.1 y 5, 43 y 176 LGT y demás normas reguladoras de cada tributo en particular, habiéndose liquidado el consorcio por vía capitular y adjudicado bienes comunes, que se transmutan en privativos, al cónyuge no deudor, resultando, en este sentido, inoponi-

${ }^{26}$ Cfr. art. 58.3 LGT.

${ }^{27}$ FERNÁNDEZ CANALES, Carmen, «La responsabilidad derivada del art. 1366 del Código Civil», Práctica Derecho de Daños, n. . 117, 2013, pág. 9 de la versión digital obrante en laleydigital360 (LA LEY 8050/2013).

${ }^{28}$ ALGABA ROS, Silvia, "Los bienes gananciales y su responsabilidad por las deudas tributarias. La modificación del régimen económico matrimonial en perjuicio de sus acreedores. Comentario a la Sentencia del Tribunal Supremo de 21 de junio de 2005 (RJ 2005, 6424)», Revista de Derecho Patrimonial, n. ${ }^{\circ}$ 17, 2006, pág. 5 de la versión electrónica (BIB 2006\1080). 
ble a la Administración tributaria acreedora esa novación capitular y perviviendo la vinculación del activo social atribuido al mismo por esas deudas de acuerdo con los arts. 1317 y 1401 CC. La calificación ganancial de la deuda del cónyuge responsable subsidiario en esta hipótesis (cuya responsabilidad podría extenderse a las sanciones), la cual existe fiscalmente en la medida en que se ha verificado el presupuesto habilitante de la respectiva responsabilidad previsto en la legislación tributaria, y la potencial ejecución del extinto caudal común adjudicado se anudarían a que ese concreto débito tributario surgiera previamente a la disolución de la sociedad, a lo que no obsta que la responsabilidad subsidiaria se declare con carácter posterior, infiriéndose esa consorcialidad al enmarcarse la actuación del cónyuge administrador en el ámbito de su actividad profesional o comercial ex art. $1365.2 .^{\circ}$ CC y 6 y ss. CCo. En definitiva, coexisten, por lo tanto, en esta sede dos tipos de responsabilidad independientes, la tributaria, que se rige por preceptos fiscales, y la ganancial, sometida a la normativa sustantiva del CC (y CCo $)^{29}$.

Con independencia de la atribución ex lege de consorcialidad a las deudas tributarias contraídas por cualquiera de los cónyuges en el caso del IRPF, Impuesto sobre la Renta de no Residentes e Impuesto sobre el Patrimonio, a los efectos de ponderar la sujeción ad extra de la masa común por los débitos que traigan su causa de otros tributos en los que el obligado tributario sea un cónyuge casado en gananciales habrá de atenderse al hecho imponible de cada uno de aquellos y concluir sobre aquella vinculación teniendo en cuenta las reglas del art. 1365 CC y no, a nuestro juicio, el art. 1366. De esta forma, la deuda tributaria imputable a un cónyuge habrá de ser calificada como ganancial, a título de ejemplo y sin ánimo de exhaustividad, en impuestos asociados a la actividad profesional o comercial de aquel (como acontece con el IVA, ex arts. 4 y ss. LIVA $^{30}$ ), por aplicación de los arts. $1365.2 .{ }^{\circ}$ CC y 6 y ss. CCo, $\mathrm{o}$, asimismo, cuando se grava la titularidad de derechos exclusiva de un cónyuge sobre bienes inmuebles - IBI (Impuesto sobre Bienes Inmuebles), ex arts. 61 y 63 TRLRHL $^{31}$-, dado que, en este último supuesto, la exacción del débito en cuestión se configura como un acto de administración ordinaria de los propios bienes en el sentido concretado en el art. 1365.2. ${ }^{\circ}$, inciso segundo, CC.

${ }^{29}$ Cfr., entre otras muchas, STS de 19 de febrero de 2014 (Cendoj-ECLI:ES:TS: 2014:638), SAP de León de 16 de noviembre de 2011 (Cendoj-ECLI:ES:APLE:2011:1290) y SAP de Zamora de 22 de noviembre de 2016 (Cendoj-ECLI:ES:APZA:2016:379).

${ }^{30}$ Vid. arts. 4 y ss. ex Ley 37/1992, de 28 de diciembre, del Impuesto sobre el Valor Añadido.

${ }^{31}$ Cfr. arts. 61 y 63 del Real Decreto Legislativo 2/2004, de 5 de marzo, por el que se aprueba el texto refundido de la Ley Reguladora de las Haciendas Locales.

(C) UNED. Revista de Derecho UNED, núm. 22, 2018 
Si se incardina la deuda tributaria en el ámbito material del art. 1366 y se aboga, lo que no admitimos, por la proyección de la excepción legal establecida en aquel precepto también en la relación externa, podría inferirse teóricamente que la conducta dolosa o gravemente negligente del cónyuge que no satisface determinados tributos o que comete otras irregularidades de orden fiscal, verificada dentro del marco predefinido en la disposición, traería consigo la no calificación como gananciales de los respectivos débitos tributarios frente a la Administración Tributaria y, añadidamente, la exclusión del gasto producido como carga definitiva comunitaria, algo que habría de reputarse difícilmente inteligible, en atención a lo que, a efectos de soslayar esta incoherencia del sistema que trasluce la interpretación literal de la norma, parece más oportuno subsumir, a pesar de su etiología no contractual, la deuda de naturaleza fiscal, según se entiende en múltiples resoluciones judiciales, en el art. 1365 CC $^{32}$.

Por lo que respecta a los inmuebles gananciales, el abono del IBI relativo a ellos constituirá una deuda tributaria consorcial de conformidad con la normativa fiscal reguladora del indicado tributo, en relación, a su vez, con los arts. 1367 y 1369 CC y 35.7.1 LGT, quedando, de esta forma, solidariamente obligados cada uno de los cónyuges sujetos pasivos, frente a la Administración Tributaria, al cumplimiento de todas las prestaciones, toda vez que se produce una realización conjunta del hecho imponible, de donde resulta la ganancialidad del débito y, consecuentemente, el compromiso directo e indistinto de las tres masas patrimoniales concernidas ${ }^{33}$.

${ }^{32}$ Cuando estamos en presencia de un tributo vinculado a la actividad profesional o comercial de un cónyuge, como sucede con el IVA, no tendría sentido otorgarle un tratamiento jurídico no homogéneo a la deuda tributaria que dimana de aquella (art. 1366) y a los restantes débitos que surgen en el marco de esas actividades conyugales (arts. 1365.2. ${ }^{\circ}$ CC y 6 y ss. CCo), no obstante su diversa naturaleza (no contractual/contractual), absorbiendo, así, en nuestra opinión, la noción de deuda profesional o comercial ganancial aquellos débitos tributarios contraídos por los cónyuges que provengan en último término de la realización de las citadas actividades.

${ }^{33} \mathrm{El}$ art. 35.7.1 LGT dispone que «la concurrencia de varios obligados tributarios en un mismo presupuesto de una obligación determinará que queden solidariamente obligados frente a la Administración tributaria al cumplimiento de todas las prestaciones, salvo que por ley se disponga expresamente otra cosa».

En cuanto a la condición ganancial de las deudas referentes al IBI de bienes comunes, la STS de 20 de junio de 2006 (Cendoj-ECLI:ES:TS:2006:3722) proclama aquella expresando que se trata de un impuesto municipal de carácter real, cuyo hecho imponible es la propiedad de bienes inmuebles. La naturaleza ganancial de los débitos por IBI de inmuebles del consorcio se mantiene asimismo en la SAP de Barcelona de 15 de marzo de 2010 (Cendoj-ECLI:ES:APB:2010:2900), la cual alude al art. 1367 CC, y por la SAP de Cantabria de 27 de enero de 2010 (CendojECLI:ES:APS:2010:158). 
Las sanciones económicas, tributarias, en materia de la Seguridad Social o de otro tipo, que se impongan a cualquiera de los cónyuges, las cuales, en atención a su origen legal, poseen naturaleza extracontractual, constituyen deudas privativas en virtud del principio de personalidad de la pena o sanción plasmado en el art. $25 \mathrm{CE}$ y, en consecuencia, no sujetan erga omnes o frente a la Administración los bienes comunes, como ha declarado el $\mathrm{TS}^{34}$, no obstante lo cual en la doctrina judicial existen numerosas resoluciones que, en función de las circunstancias singularmente concurrentes en cada supuesto, concluyen la vinculación del acervo consorcial por aquellos débitos individualmente generados ${ }^{35}$.

La indudable privatividad de las deudas que traigan su causa de sanciones que hayan sido impuestas a alguno de los cónyuges casados en gananciales, admitida, por lo demás, por la doctrina constitucional, no va a impedir, como deviene lógico y congruente con esa condición de deuda propia, que la Administración pueda trabar y realizar bienes gananciales para la exacción de los citados débitos ante la carencia o insuficiencia del patrimonio privativo del sujeto infractor, sin perjuicio del ejercicio del derecho de sustitución por el consorte de este, en los términos que resultan del art. 1373 CC y 541.3 LEC $^{36}$.

Se ha cuestionado la extensión de la responsabilidad solidaria y subsidiaria a las sanciones pecuniarias prevista en la LGT, toda vez que ello contradice el principio de personalidad de la sanción, entendiéndose que la sanción pecuniaria es un castigo y que este aspecto no puede descuidarse cuando se procede a su recaudación, que ha de

${ }^{34}$ STS de 19 de febrero de 1992 (Cendoj-ECLI:ES:TS:1992:12628).

${ }^{35}$ Entre las resoluciones de las Audiencias Provinciales que excluyen la ganancialidad de las sanciones económicas impuestas a uno de los cónyuges podemos citar la SAP de Oviedo de 29 de noviembre de 2013 (CendojECLI:ES:APO:2013:3466) y la SAP de La Rioja de 30 de enero de 2015 (CendojECLI:ES:APLO:2015:83). Contrariamente, también existen resoluciones que admiten la sujeción externa del acervo común por las sanciones pecuniarias impuestas a un cónyuge y, así, en este sentido, entre otras, la SAP de Ávila de 17 de enero de 2012 (Cendoj-ECLI:ES:APAV:2012:13), la SAP de Córdoba de 12 de junio de 2012 (CendojECLI:ES:APCO:2012:1524) y la SAP de Salamanca de 31 de marzo de 2009 (CendojECLI:ES:APSA:2009:115).

${ }^{36}$ Cfr. STC 36/2000, de 14 de febrero de 2000 (BOE n. ${ }^{\circ}$ 66, Suplemento, de 17 de marzo de 2000, págs. 15 a 22). Argumenta el TC en esta resolución, que avala el embargo de numerario presuntivamente ganancial depositado en cuentas de la titularidad de la esposa del sujeto infractor ex art. 1373, que, si bien de acuerdo con el principio de personalidad de la pena o sanción consagrado en el art. $25 \mathrm{CE}$ no cabe imponer una sanción pecuniaria a quien no es responsable de la misma, ello no excluye que se pueda proceder al cobro de aquella con bienes del cónyuge del mencionado infractor si, de acuerdo con las normas reguladoras del régimen patrimonial del matrimonio, los mismos tienen el carácter de gananciales.

(C) UNED. Revista de Derecho UNED, núm. 22, 2018 
sujetarse a las garantías materiales y formales de los arts. 25 y $24 \mathrm{CE}$, de forma que si el comportamiento de los responsables se considera merecedor del reproche del ordenamiento por su participación en la perpetración de ilícitos lo que procede es imponerles una sanción, siguiendo el cauce del procedimiento sancionador ${ }^{37}$.

En la hipótesis de que un cónyuge sea responsable solidario o subsidiario del pago de una sanción tributaria, derivada o no de una deuda tributaria, y, por tanto, no tenga la condición de sujeto infractor, esa exigencia de responsabilidad es materialmente sancionado$\mathrm{ra}^{38}$, teniendo, subsiguientemente, el débito correspondiente naturaleza privativa, aunque no se le imponga propiamente la sanción al cónyuge que se ve compelido a satisfacerla ${ }^{39}$.

\section{III.C. El régimen de responsabilidad por obligaciones extracontractuales asumidas por un cónyuge en algunos sistemas de comunidad del Derecho comparado}

Refiriéndonos al Derecho comparado, en el ordenamiento francés, ex art. 1417.1 del Code, se excluyen del pasivo definitivo o interno de la communauté légale ${ }^{40}$ (y forman parte, por lo tanto, del pasivo definitivo propio del deudor) las obligaciones extracontractuales contraídas por un cónyuge, las cuales, ex art. $1413 \mathrm{CC}$, vincularán provisionalmente frente a terceros los bienes comunes ${ }^{41}$, disponiendo el primer precepto que la comunidad tiene derecho a recompensa, deducido, en su caso, el benefi-

${ }^{37}$ MARTÍNEZ LAGO, Miguel Ángel, La extensión de la responsabilidad a las sanciones tributarias, Tirant lo Blanch, Valencia, 2008, págs. 160-161.

${ }^{38} \mathrm{Vid}$. STC 85/2006, de 27 de marzo de 2006 (BOE n. ${ }^{\circ}$ 106, de 4 de mayo de 2006, págs. 11-25).

${ }^{39}$ Cfr. arts. 181 y 182 LGT.

${ }^{40}$ Sobre la dislocación entre pasivo provisional (obligation à la dette) y pasivo definitivo (contribution à la dette) en el régimen de la comunidad legal, Gilles GOUBEAUX [en VOIRIN, Pierre, Droit civil (Droit privé notarial. Régimes matrimoniaux. Successions-Libéralités), T. 2, 22. ${ }^{a}$ ed., Librairie Générale de Droit et de Jurisprudence, París, 2002, pág. 66] destaca que la respuesta a la cuestión de cuáles son las deudas por las que responden los bienes comunes determina el pasivo provisional de la comunidad, en tanto que la respuesta al aspecto de si la comunidad que ha debido pagar una deuda conserva la carga definitiva o tiene un recurso contra un cónyuge es la que determina, por su parte, el pasivo definitivo. En esta línea, vid. Frédéric LUCET y Bernard VAREILLE, Droit civil (Régimes matrimoniaux, libéralités, successions), 4. ${ }^{\text {a }}$ ed., Dalloz, París, 2001, pág. 68.

${ }^{41}$ Determina el art. 1413 CC que el pago de las deudas por las que cada cónyuge está obligado, por cualquier causa, durante la comunidad, puede ser siempre perseguido sobre los bienes comunes, a menos que haya habido fraude por parte del cónyuge deudor y mala fe del acreedor, salvo la recompensa debida a la comunidad si ha lugar. 
cio obtenido por ella ${ }^{42}$, cuando haya pagado las multas contraídas por un cónyuge, como consecuencia de infracciones penales, o las reparaciones y gastos a los que fue condenado por delitos o cuasidelitos civiles ${ }^{43}$.

Por su parte, en el Derecho civil portugués, el art. 1692.b) del Código civil, aplicable al régimen económico matrimonial supletorio de la comunhão de adquiridos, establece que son de la exclusiva responsabilidad del cónyuge deudor las deudas provenientes de delitos y las indemnizaciones, restituciones, costas judiciales o multas debidas por hechos imputables a cada uno de los cónyuges $^{44}$, salvo que esos hechos, implicando responsabilidad meramente civil, estén cubiertos por lo dispuesto en el art. 1691.1 y $2^{45}$, que relaciona los débitos que

${ }^{42}$ Con respecto a la deducción del beneficio obtenido por la comunidad, remarca Rémy CABRILLAC (en Droit civil. Les régimes matrimoniaux, $4 .^{\mathrm{a}}$ ed., Montchrestien, París, 2002, pág. 169) que si las actuaciones de los cónyuges han beneficiado a la comunidad la misma deberá deducir este beneficio de su crédito de recompensa, siendo tal el caso si un cónyuge, como consecuencia de una estafa, ha comprado bienes de los cuales la comunidad se ha beneficiado.

${ }^{43}$ En relación con esta disposición, dice André COLOMER (en Droit civil. Régimes matrimoniaux, $4 .^{a}$ ed., Litec, París, 1990, pág. 410) que la idea que está en el origen del carácter a priori definitivo de los débitos contraídos por un cónyuge en el marco de sus poderes de gestión de bienes comunes no se vislumbra respecto de las deudas extracontractuales, comprendiéndose así que el art. 1417 únicamente englobe en el pasivo provisional — passif provisoire - de la communauté las deudas delictuales y cuasidelictuales civiles, así como las multas impuestas por razón de infracciones penales. Infiere COLOMER que la ausencia en este punto de correlación entre obligación y contribución a la deuda es legítima y solo el interés por proteger a los terceros justifica el ingreso de esas obligaciones en la comunidad, deviniendo justo que en estas condiciones que aquella pueda reclamar una recompensa.

La incardinación en el pasivo propio del cónyuge deudor de las deudas extracontractuales relacionadas en el art. 1417.1 del Code, como afirman Philippe MALAURIE y Laurent AYNÈS (en Cours de Droit civil. Les régimes matrimoniaux, Éditions Cujas, París, 1988, pág. 233), halla su fundamento en el principio de personalidad de las penas.

${ }^{44}$ Las indemnizaciones, restituciones, costas judiciales o multas debidas por hechos imputables a cada uno de los cónyuges de las que habla el art. 1692.b), según Fernando A. PIRES DE LIMA y João de Matos ANTUNES VARELA [en Código Civil anotado, Vol. IV (Artigos 1576. ${ }^{\circ}$ a $1795 .^{\circ}$ ), 2. $^{\text {a }}$ ed., Coimbra Editora, Limitada, 1992, pág. 342], incluyen no solo los supuestos de responsabilidad civil conexa con la criminal (obligación de indemnizar los daños materiales o morales causados por la comisión de delitos), sino también las situaciones de responsabilidad civil extracontractual o delictual, ya se funde la responsabilidad en la realización de hechos ilícitos, ya se base en el riesgo, dado que el uso de la expresión factos imputáveis (hechos imputables) no permite excluir la responsabilidad objetiva.

${ }^{45}$ En opinión de Francisco PEREIRA COELHO y Guilherme DE OLIVEIRA [en Curso de Direito da família, Vol. I (Introdução. Direito matrimonial), 5. a ed., Imprensa da Universidade de Coimbra, Coimbra, 2016, pág. 495], en la fórmula del art. 1692.b) CC se quieren comprender todos los hechos constitutivos de responsabilidad civil, conexa o no con la responsabilidad criminal, ya se trate de hechos ilícitos o lícitos, culposos o no culposos.

(C) UNED. Revista de Derecho UNED, núm. 22, 2018 
son responsabilidad de ambos cónyuges, respondiendo ex art. 1696 por esas deudas extracontractuales los bienes propios del cónyuge deudor y, subsidiariamente, su mitad en los bienes comunes ${ }^{46}$.

En cuanto al Derecho italiano, este carece de una norma que, en el ámbito de la comunidad de bienes —comunione legale-, prevea específicamente el régimen de sujeción por las deudas extracontractuales contraídas por un cónyuge, catalogándose las mismas, bien como privativas del cónyuge deudor ${ }^{47}$, bien como comunes, al amparo en este caso del art. 186.b) CC, que alude, entre las obligaciones que gravan los bienes de la comunidad legal, a todas las cargas de la administración —carichi dell'amministrazione - ${ }^{48}$.

${ }^{46} \mathrm{Al}$ mismo tiempo que los bienes propios del cónyuge deudor, responden por las deudas privativas ex art. 1696.2 los bienes aportados por aquel al matrimonio o adquiridos posteriormente a título gratuito, así como los respectivos rendimientos y los subrogados de estos bienes, y el producto del trabajo y los derechos de autor del citado cónyuge.

Para ANTUNES VARELA (en Direito da família, Livraria Petrony, Lisboa, 1987, pág. 392), si los hechos relacionados en la norma fueran ejecutados por ambos cónyuges, la responsabilidad de cada uno de ellos, medida a través de algunos factores personales, no se comunica al otro. Asimismo, expresa ese autor que la obligación de indemnizar que deriva del incumplimiento de un contrato formalizado en interés del matrimonio por el cónyuge administrador, en el marco de sus poderes, responsabilizará a ambos cónyuges.

${ }^{47}$ Esta naturaleza privativa del débito extracontractual generado por cada uno de los cónyuges se mantiene, en defecto de mención legal expresa, por exclusión, por Vincenzo DE PAOLA y Antonio MACRI (en Il nuovo regime patrimoniale della famiglia, Giuffrè Editore, Milán, 1978, págs. 195-196).

Si la obligación extracontractual se reputa como deuda propia del cónyuge que la contrajo, con arreglo al art. 189.2 ex Codice civile, los acreedores podrán atacar por aquella subsidiariamente los bienes comunes, hasta el valor correspondiente a la cuota del cónyuge obligado. Si los acreedores particulares de un cónyuge son quirografarios, como establece ese precepto, tienen preferencia sobre ellos los acreedores comunes, lo que significa, según afirma Luigi MOSCO [en Diritto di famiglia (Matrimonio-Regime patrimoniale della famiglia-Filiazione legittima e naturale), Dott. Francesco Cacucci Editore, Bari, 1977, pág. 194], que si los acreedores de un solo cónyuge no tienen un título particular de prelación, es decir, son acreedores puros y simples, no pueden satisfacerse ni siquiera de esa manera subsidiaria, porque tendrán siempre preferencia respecto de los mismos los acreedores de la comunidad.

${ }^{48}$ Francesco CORSI [en Il regime patrimoniale della famiglia, I (I rapporti patrimoniali tra coniugi in generale. La comunione legale), en CICU y MESSINEO, Trattato di Diritto Civile e Commerciale, Vol. VI-t. I, sez. 1, Dott. A. Giuffrè Editore, Milán, 1979, pág. 159] residencia en la categoría de cargas de la administración del art. 186.b) CC las obligaciones derivadas de la responsabilidad extracontractual. En parecido sentido, Alessandra ARCERI (en I regimi patrimoniali della famiglia in prospettiva europea, Giuffrè Editore, Milán, 2016, pág. 96) constata que una parte nutrida de la doctrina mantiene que en la reseñada categoría se comprenden las obligaciones ex delicto, derivadas de errores y/o omisiones en la gestión, custodia y administración de los bienes comunes. Siguiendo similar orientación, Francesco GALGANO [en Trattato di Diritto Civile, V. I (Le categorie generali. Le persone. La 


\section{LA ACTUACIÓN CONYUGAL SEPARADA CONTEMPLADA EN EL ART. 1366 CC}

La actuación conyugal unilateral generadora de la deuda extracontractual ganancial, como explicita el art. 1366, ha de estar preordenada, al menos formal o aparentemente, al beneficio material o inmaterial, directo o indirecto, inmediato o mediato, de la sociedad conyugal, resultando irrelevante a los efectos de una eventual sujeción erga omnes del consorcio que, finalmente, se alcance o no el reiterado beneficio, según se deriva del empleo de la locución en beneficio de la sociedad conyugal, expresión esta que hace referencia simplemente a una actuación tendencialmente beneficiosa o provechosa para la comunidad ganancial y no a la obtención efectiva de un provecho o utilidad, o bien producirse en el marco de la administración, ordinaria o extraordinaria, de bienes privativos o gananciales, excluyéndose, en cualquier caso, la carga de la sociedad legal por el gasto producido si las obligaciones extracontractuales individualmente contraídas provienen de una conducta del cónyuge deudor dolosa o gravemente culposa ${ }^{49}$.

proprietà. La famiglia. Le successioni. La tutela dei diritti), Cedam, Padova, 2009, pág. 649] subsume en la noción de carichi dell'amministrazione una parte de las obligaciones de fuente no contractual, en concreto, las de resarcimiento del daño de las cosas (arts. 2051-53 y 2054.3), cuando el daño ha sido ocasionado por las cosas comunes, siendo personal del cónyuge, a los efectos del art. 189.2 CC, cualquier otra obligación extracontractual.

En el caso de calificarse como deuda común la obligación extracontractual producida por un cónyuge responderán por aquella directamente los bienes comunes y, conforme al art. 190 del Codice, en vía subsidiaria, los bienes personales de cada uno de los cónyuges, en la medida de la mitad del crédito, cuando los bienes de la comunidad resulten insuficientes para abonar el mencionado débito.

${ }^{49}$ Para Tomás GIMÉNEZ DUART (en «Cargas y obligaciones del matrimonio», $R D P$, n. ${ }^{\circ} 66,1982$, pág. 550, nota 15 ) es precisa una interpretación correctora del materialismo del art. 1366 para comprender cualquier actuación en interés familiar, existiendo un muy amplio arbitrio judicial en la aplicación de la norma. Según el citado autor, cualquier actuación que no sea contraria a los intereses familiares ha de ser incluida en el espíritu de la reseñada disposición. Sostiene también una tesis amplia BARCELÓ DOMÉNECH (en Responsabilidad de los bienes gananciales por las obligaciones extracontractuales..., cit., págs. 95-96), que excluye que cuando el precepto habla de beneficio pueda entenderse este concepto en un sentido exclusivamente económico, aunque el beneficio de la sociedad conyugal sea más claro en actividades relacionadas directamente con los ingresos de un cónyuge que nutren la comunidad ganancial, como acontece en el supuesto de las obligaciones extracontractuales asumidas en el desempeño de la profesión u oficio, si bien nada impide la existencia de «beneficio de la sociedad conyugal» en actividades que no estén vinculadas a aspecto patrimonial alguno, resultando, por otra parte, indiferente que exista o no beneficio, siendo suficiente con que la actuación tienda a su obtención. La incardinación en el ámbito del art. 1366 de obligaciones que surgen por actuaciones de uno de los cónyuges que no posean una directa finalidad

(C) UNED. Revista de Derecho UNED, núm. 22, 2018 
La noción de actuación en beneficio de la sociedad conyugal no posee un idéntico alcance en la órbita intraconyugal y en la relación externa, en línea, por lo demás, con la virtualidad de la mera apariencia en el sistema ganancial para la vinculación directa de la masa común frente a terceros por la conducta unilateral de los cónyuges. De esta manera, para que el débito extracontractual contraído por un cónyuge comprometa externamente el haber social no es preciso que este haya actuado efectivamente en beneficio del consorcio, sino que basta con que formalmente lo parezca y tal circunstancia se acredite por el acreedor, pudiendo inferirse la actuación en beneficio en aquellas actuaciones separadas que conectan en un sentido amplio con el interés familiar y hasta deducirse de la mera inexistencia de perjuicio notorio como consecuencia de los actos ejecutados en la esfera familiar. Será en la relación ad intra, y en orden a la posible imputación última del desembolso realizado al pasivo ganancial interno, donde debe ponderarse si aquella actuación realmente estaba orientada al logro de un beneficio o utilidad para la sociedad de gananciales y, de no ser así, el gasto en cuestión no tendrá la catalogación de carga de la comunidad, lo que dará lugar, de haberse satisfecho la obligación a costa del caudal consorcial, al pertinente reintegro a favor de la misma en fase de liquidación.

Por lo que respecta a las obligaciones extracontractuales que se contraigan por un cónyuge en el ámbito de la administración de los bienes, solamente indicar que la falta de concreción del precepto permite reputar comprendida en la mención legal tanto la administración ordinaria como la extraordinaria ${ }^{50}$ de bienes propios o comunes ${ }^{51}$, habiendo de destacarse, como constata RAGEL, que, en este

patrimonial se comparte, asimismo, por Vicente GUILARTE GUTIÉRREZ, Gestión y responsabilidad de los bienes gananciales, Lex Nova, Valladolid, 1991, pág. 402.

En opinión de RAGEL SÁNCHEZ (en El Régimen de Gananciales, cit., pág. 470), son actuaciones en beneficio de la sociedad conyugal aquellas encaminadas a atender necesidades que legalmente originan la responsabilidad contractual en los arts. 1365 y 1368 CC, obviando el cónyuge del deudor de este modo los peligros de una excesiva generalización del término beneficio.

${ }^{50}$ En relación con la categoría de los actos de administración extraordinaria, dice Pilar BENAVENTE MOREDA (en Naturaleza de la sociedad de gananciales. Legitimación individual de los cónyuges, Colegio de Registradores de la Propiedad y Mercantiles de España. Centro de Estudios Registrales, Madrid, 1993, pág. 257) que se configuran como actos que en la práctica son valorados en función de la trascendencia e importancia que despliegan sobre el patrimonio, encontrándose en el límite entre actos de administración y dispositivos, con lo que ello supone en cuanto a su régimen jurídico.

${ }^{51}$ Por bienes hay que entender, como corrobora BUSTOS MORENO (en Las deudas gananciales y sus reintegros, cit., pág. 330), tanto los de carácter ganancial como los privativos de los cónyuges, dado que los mismos constituyen las masas patrimoniales en el ámbito de la sociedad legal y carece de sentido excluir alguno de tales bienes cuando la norma no lo hace. 
aspecto, el ámbito objetivo del art. 1366 es más amplio que el contemplado en el art. 1365 para las obligaciones contractuales, dado que incluye los actos de administración extraordinaria de bienes privativos, y, de esta manera, en tanto que será privativa la deuda contractual producida en la administración extraordinaria de bienes privativos, es ganancial el débito extracontractual generado en esa administración extraordinaria ${ }^{52}$.

\section{EL JUEGO DEL DOLO O LA CULPA GRAVE DEL CÓNYUGE DEUDOR EXCLUSIVAMENTE EN LA RELACIÓN INTERNA O CARGO}

Aunque una exégesis mecanicista, rígida y literal de la dicción del art. 1366 CC sugiera lo contrario, entendemos que la operatividad de la excepción legal recogida in fine en la declaración normativa contenida en aquel precepto debe reconducirse exclusivamente a la órbita intraconyugal y producir, así, únicamente el limitado efecto de impedir que el gasto dimanante de la obligación extracontractual que sea consecuencia de la actuación dolosa o gravemente culposa del cónyuge deudor, realizada dentro del ámbito material predefinido en el artículo, se integre en el pasivo ganancial definitivo. Por lo tanto, la concurrencia de dolo o culpa grave ${ }^{53}$ en quien contrae el débito extra-

La razón de la inclusión de los supuestos de administración extraordinaria también sobre bienes privativos en el marco del art. 1366, frente a la exclusión de los gastos originados por ellos del cargo ganancial ex art. 1362, según TORRALBA SORIANO (en "Art. 1.366», Comentarios a las reformas del Derecho de familia, Vol. II, cit., pág. 1695), se encuentra en que ese artículo trata de conceder a los terceros perjudicados una amplia cobertura patrimonial, teniendo en cuenta, por otra parte, que la masa ganancial obtendrá un beneficio de esos actos, toda vez que estos probablemente producirán un aumento en los rendimientos de los bienes privativos en que se ejecutan. Sin embargo, el autor mencionado reputa lógico que el cargo definitivo de las obligaciones extracontractuales provenientes de actos de administración extraordinaria de bienes privativos afecte al haber propio del cónyuge que ha efectuado tales actos. Expresa BARCELÓ DOMÉNECH (en Responsabilidad de los bienes gananciales..., cit., pág. 98) que ha de admitirse la posibilidad de que sean de la responsabilidad y cargo de la comunidad ganancial las obligaciones extracontractuales dimanantes de la administración extraordinaria de un bien privativo, habida cuenta que, si se quisiese excluir esta situación del ámbito del art. 1366, la redacción de la norma debería haber sido más explícita.

En la Ley 84.2.1 del Fuero Nuevo de Navarra, relativa a la sociedad de conquistas, sí se determina expresamente la afección solo externa de la sociedad por las obligaciones extracontractuales contraídas por un cónyuge en la administración de los bienes privativos.

${ }^{52}$ RAGEL SÁNCHEZ, El Régimen de Gananciales, cit., pág. 470.

${ }^{53}$ En el art. 1366, entre otros preceptos, se plasma la idea clásica de la equiparación entre dolo y culpa grave (magna negligentia culpa est, magna culpa dolus est).

(C) UNED. Revista de Derecho UNED, núm. 22, 2018 
contractual no va a permitir excluir prima facie la ganancialidad de este y minorar la garantía patrimonial inherente a esta tipología de deudas en aquellos supuestos en los que, precisamente, la gravedad o ilicitud de la conducta de quien genera el débito demanda una mayor tutela de los intereses de los terceros perjudicados, que han de tener preeminencia sobre el interés del consorte del cónyuge deudor en sustraer de una eventual ejecución su mitad ganancial, y en consonancia, por lo demás, con la finalidad que orienta las reglas de responsabilidad externa que legitiman la actuación conyugal autónoma con trascendencia patrimonial directa para la sociedad legal ${ }^{54}$.

La responsabilidad consorcial externa o directa, en garantía de los derechos de los terceros, ha de sujetarse a criterios formales o de mera apariencia, difícilmente conciliables con las nociones de dolo o culpa grave, cuya vaguedad y falta de concreción, en defecto de la pertinente declaración judicial, dificultarían su objetivación y la actividad probatoria oportuna sobre su real concurrencia, singularmente cuando estamos en presencia de comportamientos dolosos o en la hipótesis de conductas en las que la valoración del grado de diligencia exigible no deviene sencillo. En consecuencia, y en aras, asimismo, de la necesaria seguridad jurídica y para obviar resultados contradictorios o incongruentes, será suficiente, para que el débito en cuestión sea calificado como ganancial, que los terceros acreedores adveren

${ }^{54}$ En concreto, en la Exposición de Motivos del Proyecto de ley de modificación del Código Civil en materia de filiación, patria potestad y régimen económico del matrimonio de 14 de septiembre de 1979, luego convertido en la Ley 11/1981, que introdujo la regulación ganancial vigente, se habla a este respecto de la consideración prioritaria de la seguridad del tráfico y los derechos de terceros, que se hace patente (...) en las posibilidades concedidas a los cónyuges de actuar "erga omnes» comprometiendo incluso los bienes comunes (Vid. BOCG, Congreso de los Diputados, Serie A, n. ${ }^{\circ}$ 71-I, de 14 de septiembre de 1979, pág. 316).

Tampoco el hecho de que durante la tramitación parlamentaria de la norma, que mantuvo la redacción inicial del Proyecto, se rechazaran dos enmiendas con idéntica pretensión, presentadas por el Grupo Vasco (PNV) -n. ${ }^{\circ} 397-$ y por el Grupo Parlamentario de Senadores Vascos $(\mathrm{SV})$-n. ${ }^{\circ}$ 6-, por la Comisión de Justicia del Congreso y de Justicia e Interior del Senado, respectivamente, en las que se defendía la supresión de la excepción legal, que se justificaba, al margen de por el riesgo de enrarecimiento de las relaciones personales entre los cónyuges, porque se decía que no parecía que la distinción entre los casos de dolo y culpa grave y el de culpa leve debiera surtir efectos frente a terceros, más aún teniendo en cuenta la dificultad que implica la valoración de los diversos grados de culpa, conduce unívocamente a colegir una voluntad legislativa proclive a la ambivalencia de la excepción, toda vez que la razón del rechazo de las enmiendas pudo obedecer a que no se compartía la exégesis sobre la aplicabilidad de aquella en la relación externa o a que se perseguía la completa supresión de la misma en las esferas externa e interna [Cfr. Código Civil (Reformas 1978-1983). Trabajos Parlamentarios, I, Cortes Generales, Madrid, 1985, págs. 336-337; y BOCG, Senado, Serie II, n. ${ }^{\circ}$ 154, de 24 de febrero de 1981, pág. 41]. 
que la obligación extracontractual se contrajo por el cónyuge en una actuación verificada en el aparente beneficio del consorcio o ejecutada formalmente en el ámbito de la administración de los bienes, suscitándose, así, de darse en esta sede un comportamiento doloso o gravemente culposo del deudor, una responsabilidad puramente provisional y directa de la masa ganancial, que provocará, en su caso, el ulterior reajuste patrimonial en la fase de contribución ${ }^{55}$.

${ }^{55} \mathrm{El}$ TS adolece de una doctrina consolidada y uniforme en cuanto a la interpretación de la excepción recogida en el art. 1366 CC y, de este modo, en la aludida STS de 31 de marzo de 2004 (Cendoj-ECLI:ES:TS:2004:2242) se parte de una exégesis literal del precepto y se afirma que «la claridad del texto legal rechaza que la excepción tenga únicamente el alcance de excluir el efecto "de cargo" de la sociedad de gananciales, de modo que su patrimonio responde frente a tercero, pero internamente, en las relaciones entre los cónyuges, la deuda no es pasivo de la sociedad. Esta limitación de los efectos de la excepción es arbitraria porque distingue donde la ley no lo hace entre "responsabilidad y cargo» de la sociedad de gananciales». Esta postura también se sigue en las SSTS de 8 de julio de 1997 (Cendoj-ECLI:ES:TS:1997:4866) y de 14 de marzo de 2002 (Cendoj-ECLI:ES:TS:2002:1848). Contrariamente, en la STS de 25 de octubre de 2005 (Cendoj-ECLI:ES:TS:2005:6469), a favor de la tesis restrictiva, se dice que «la norma del artículo 1366 CC no permite disminuir las garantías del acreedor, sino que frente al tercero funcionará la responsabilidad de la sociedad de gananciales, con independencia de las acciones que los cónyuges tengan entre ellos para el reembolso de lo pagado que no debiera ir a cargo de la sociedad". Igualmente, la comentada STS de 25 de septiembre de 1999 (CendojECLI:ES:TS:1999:5802), que admite la posible ganancialidad de la responsabilidad civil ex delicto impuesta a un cónyuge, conforme se ha expresado, declara que la excepción legal se aplica a la relación interna y limitadamente a la externa, según la ratio del artículo.

Para BELLO JANEIRO (en La defensa frente a tercero..., cit., pág. 413), como la supresión de la excepción postulada en las dos enmiendas antes citadas no se verificó, procede concluir, ex art. 3.1 CC, que la conducta dolosa o gravemente culposa del cónyuge deudor que origina la obligación extracontractual determina la exclusión de la misma de la responsabilidad y cargo de la sociedad ganancial. Alcanza la misma conclusión GUILARTE GUTIÉRREZ (en Gestión y responsabilidad..., cit., págs. 403-405), quien expresa que la literalidad del precepto ha de prevalecer y que, por lo tanto, la existencia de dolo o culpa grave libra de todo tipo de responsabilidad a la masa consorcial e, igualmente, de la deuda originada. Explica GUILARTE que el legislador ha sopesado el interés del cónyuge no actuante y el de los terceros acreedores, colocando en este supuesto el fiel que inclina la balanza hacia uno u otro lado en la circunstancia de que en la actividad que produce la responsabilidad extracontractual medie o no dolo o culpa grave, de forma que existiendo estos cabe reputar que el otro cónyuge no ha de asumir, ni provisionalmente, las consecuencias perjudiciales de la reseñada actividad. En esta línea, BUSTOS MORENO (en Las deudas gananciales..., cit., pág. 336) mantiene que la actuación conyugal con dolo o culpa grave a la hora de contraer la obligación extracontractual no responsabiliza en ninguna de las esferas al caudal ganancial, reconociendo que esta interpretación no es la más beneficiosa para el acreedor. Compartiendo esta orientación, cfr. ALBALADEJO, Manuel, Curso de Derecho civil, IV (Derecho

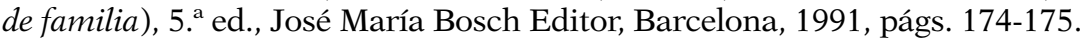

Asumiendo, como proponemos, el juego de la excepción legal exclusivamente en la relación interna, GIMÉNEZ DUART (en «Cargas y obligaciones del matrimonio», cit., pág. 550) sostiene que considerar que el tercero verá disminuida su garantía de

(C) UNED. Revista de Derecho UNED, núm. 22, 2018 
La interpretación de la norma que propugnamos se realiza, por consiguiente, atendiendo fundamentalmente al espíritu y finalidad de aquella, tal como prescribe el art. $3.1 \mathrm{CC}$, por cuanto que, según se ha dicho, la voluntad legislativa expresada es proteger prevalentemente los derechos de los terceros, contratantes o no contratantes, algo que es escasamente compatible con una aplicación literal de la Ley que puede conducir a resultados no convincentes o ilógicos, de modo que, en línea, por otra parte, con el antecedente normativo inmediato que representa el derogado art. 1410.3 ex CC 1889, el cual, como se ha reiterado, establecía una responsabilidad provisional y subsidiaria de la masa común por los débitos extracontractuales (privativos) contraídos por un cónyuge, aún existiendo dolo o culpa grave de este último, no parece que deba vaciarse sustancialmente de contenido la regla de responsabilidad externa del art. 1366, de admitirse la virtualidad del dolo o culpa grave en el plano ad extra, en aquellas hipótesis que, precisamente, reclaman una mayor protección de los terceros acreedores por las obligaciones extracontractuales previstas legalmente, quienes, en nuestra opinión, deben contar inexcusablemente con la garantía patrimonial del caudal ganancial íntegro ${ }^{56}$.

cobro cuanto mayor sea la culpabilidad del deudor, es decir, a mayor ilicitud, menos responsabilidad, puede producir situaciones grotescas, viéndose forzado el demandante damnificado a inculpar al demandado no demasiado para no perder la afección de los gananciales, por lo que entiende que ha de reducirse la norma por vía de interpretación a sus justos límites y concluir que la excepción alude al cargo o aspecto interno, pero no a la responsabilidad o garantía de los terceros. Esta postura es suscrita también por LACRUZ (en Elementos..., IV, Vol. 1. ${ }^{\circ}$, cit., pág. 429) teniendo en cuenta los antecedentes inmediatos de la norma. De la misma forma, TORRALBA SORIANO (en «Art. 1.366», Comentarios a las reformas..., Vol. II, cit., pág. 1700) se muestra partidario de esta interpretación porque es la más coherente con la finalidad esencial del art. 1366, la cual consiste en ampliar el círculo de los bienes responsables ante la actuación del cónyuge que provoca el surgimiento de una obligación extracontractual. A su vez, María Mercedes ALBERRUCHE DÍAZFLORES [en «Pactos entre progenitores para distribuir su responsabilidad por los actos de sus hijos», La Ley Derecho de familia, n. ${ }^{\circ}$ 5, 2015, pág. 6 de la versión digital obrante en laleydigital360 (LA LEY 25/2015)] indica que, para obviar injustas incongruencias jurídicas, se concluye mayoritariamente que la excepción contempla tan solo la responsabilidad definitiva o interna y no la provisional o de garantía frente a terceros.

Por su parte, DE LOS MOZOS [en "Artículo 1.366», en Comentarios al Código Civil..., T. XVIII, Vol. 2. ${ }^{\circ}$, cit., pág. 298] destaca que la excepción juega plenamente en la relación interna y limitadamente en la externa, no impidiendo en esta última la valoración del comportamiento en el grado de culpabilidad que el acreedor se dirija directamente contra los bienes comunes. Cuando la culpa grave o el dolo estén ya definidos, en su criterio (ibíd., pág. 298, nota 19), el acreedor no podrá actuar de modo directo contra los bienes gananciales, debiendo seguirse el procedimiento determinado en el art. 1373 CC.

${ }^{56}$ La reconducción de la operatividad del dolo o la culpa grave del cónyuge deudor por obligaciones extracontractuales a la relación interna o cargo y la consecuente 
Ahondando en lo argüido, y dejando al margen que no es fácilmente comprensible colegir que la evolución normativa, frente a lo establecido en el régimen ganancial original de 1889 en este aspecto, suponga un detrimento de los derechos de los acreedores de los cónyuges por débitos extracontractuales por lo que respecta a la extensión de la garantía de sus créditos, consideramos que resultaría contradictorio que, por una parte, el legislador de 1981 incluya extensivamente en el ámbito material del art. 1366 cualquier actuación en beneficio de la sociedad conyugal ${ }^{57}$ y, por otra, de admitirse la aplicabilidad de la excepción en la órbita externa, simultáneamente, prescinda de tal circunstancia y restrinja el marco de ganancialidad pasiva de concurrir dolo o culpa grave en la conducta del deudor que actúa en provecho del consorcio. Si se asume que la propia voluntad del deudor o la mayor entidad del reproche de culpabilidad que se haga a aquel determinarán la privatividad de la obligación extracontractual en el sistema ganancial, se estaría privilegiando impropiamente el interés del consorte no deudor e inutilizando significativamente el precepto al dejar fuera de la esfera de responsabilidad directa una gran parte de los supuestos más relevantes de responsabilidad civil extracontractual, toda vez que la concurrencia del elemento

afección externa de la masa común por aquellas está recogida, en el ámbito de la sociedad de conquistas, en la Ley 84.2.1 del Fuero Nuevo de Navarra, que declara que las obligaciones extracontractuales que se contraigan en relación con la administración de los bienes privativos o sean debidas a dolo o culpa grave del cónyuge deudor será de responsabilidad pero no de cargo de la sociedad. Esta irrelevancia de la conducta dolosa o gravemente culposa del deudor en la relación con terceros se plasma igualmente en el art. 219.1.b) del Código del Derecho Foral de Aragón, que admite la vinculación directa del consorcio por débitos indemnizatorios contraídos por un cónyuge, expresando aquella norma que frente a terceros de buena fe, los bienes comunes responden siempre del pago de las indemnizaciones por daños a terceros causados en el ejercicio de una actividad objetivamente útil a la comunidad, aun por dolo o culpa grave, matizándose en el art. 218.1.f) que las indemnizaciones debidas por daños a terceros causados con dolo o culpa grave solo constituyen carga del patrimonio común hasta el importe del beneficio obtenido con la actividad en la que se causó el daño.

${ }^{57}$ En el fallido Proyecto de ley sobre régimen económico matrimonial en el Código Civil de 4 de octubre de 1978, la primera versión del art. 1366 disponía que las obligaciones de carácter extracontractual contraídas en el ámbito de la administración de la sociedad serán a cargo de ésta, salvo si fueren debidas a dolo o culpa grave de uno solo de los cónyuges (cfr. BOC n. ${ }^{\circ}$ 155, de 4 de octubre de 1978, págs. 3371-3372). Por tanto, como es de apreciar, en esta propuesta inicial el precepto operaba en la relación interna y la excepción, en consecuencia, excluía únicamente la carga de la sociedad. En el Proyecto de ley de 14 de septiembre de 1979, cuyo art. 1366 coincide con el finalmente aprobado, lo que se produce es una ampliación del ámbito objetivo de la norma (al adicionarse la actuación en beneficio de la sociedad conyugal) y, asimismo, la atribución expresa de carácter ganancial a la obligación extracontractual, manteniéndose, singularmente, la excepción en el inciso final de la norma. 
de la culpa sigue siendo exigible ex art. $1902 \mathrm{CC}^{58}$, las deudas indemnizatorias provenientes de ilícitos penales perpetrados por un cónyuge aún cuando el consorcio se haya lucrado con los mismos, y, en su caso, también obligaciones legales de los cónyuges que traigan su causa de una actuación intencionada o gravemente negligente. Estas situaciones, por devenir carentes de lógica e inconciliables con el carácter tuitivo de los derechos de los terceros que inspira las reglas de responsabilidad externa de la comunidad conyugal, imponen, a nuestro juicio, concluir la virtualidad de la excepción en la relación interna, en la que habrán de ponderarse la concurrencia de conducta dolosa o el grado de culpabilidad del deudor y operarse el reembolso que pueda corresponder a favor de la sociedad.

Finalmente, en relación con la noción de dolo, se afirma que este concurrirá cuando exista propósito de causar un daño injustamente a otro, implicando la conciencia y voluntad de dañar, en tanto que la culpa habrá de calificarse como lata o grave si el grado de imprudencia o negligencia en que incurre el culpable sea de tal entidad que no hubiera incidido en la misma ni el menos cauto o precavido de los hombres ${ }^{59}$.

\section{CONCLUSIÓN}

Las deudas de naturaleza extracontractual producidas por un cónyuge, categoría que abarca expansivamente aquellas obligaciones de etiología no contractual, entre ellas, señaladamente, la responsabilidad civil derivada de ilícitos penales y no las obligaciones fiscales, preferiblemente subsumibles en el marco del art. 1365 CC, habrán de ser reputadas como gananciales y afectarán ad extra el patrimonio común si se advera por el acreedor que la actuación conyugal separada que las

${ }^{58}$ Declara la STS de 18 de marzo de 2016 (Cendoj-ECLI:ES:TS:2016:1161) que «la creación de un riesgo, del que el resultado dañoso sea realización, no es elemento suficiente para imponer responsabilidad (objetiva o por riesgo), ni siquiera cuando la actividad generadora del riesgo sea fuente de lucro o beneficio para quien la desempeña. Se requiere, además, la concurrencia del elemento de la culpa (responsabilidad subjetiva), que sigue siendo básico en nuestro Derecho positivo a tenor de lo preceptuado en el artículo 1902 CC, el cual no admite otras excepciones que aquellas que se hallen previstas en la Ley».

${ }^{59}$ GÓMEZ DE LA ESCALERA, Carlos Rafael, «Las obligaciones extracontractuales de un cónyuge y el nuevo régimen de responsabilidad de los bienes gananciales», Diario La Ley, n. ${ }^{\circ}$ 1, 1985, pág. 5 de la versión electrónica obrante en laleydigital360 (LA LEY 17952/2001). Por lo que hace referencia al dolo, apunta LACRUZ (en Elementos..., IV, Vol. 1. ${ }^{\circ}$, cit., pág. 429) que el dolo del deudor no alude a la mera intención de delinquir, sino a la intención de causar daño a la sociedad conyugal. 
genera se ajusta formalmente al ámbito material del art. 1366 CC, es decir, si la misma está orientada al beneficio, material o inmaterial, de la comunidad conyugal, debiendo entenderse que ello acaece cuando el acto en cuestión conecta con el interés familiar en un sentido amplio, o si aquella se ejecuta en la esfera de la administración, ordinaria o extraordinaria, del patrimonio propio de cualquiera de los cónyuges o del consorcial. En todo caso, no existe ya prima facie una asimilación o correlación perfecta en esta órbita extracontractual entre responsabilidad directa e interna, por cuanto que la conducta dolosa o gravemente culposa del cónyuge deudor, no obstante el tenor literal del art. 1366 CC, para soslayar resultados inconsecuentes o ilógicos en el sistema ganancial, tan solo tiene la virtualidad de excluir el cargo, pero no el eventual compromiso del acervo común frente a los acreedores, cuya garantía patrimonial, específicamente en los supuestos de mayor gravedad, no puede verse minorada en función de la concurrencia o no de dolo o culpa grave en el cónyuge que asume la deuda, circunstancia esta de difícil objetivación en defecto de declaración jurisdiccional al respecto y ajena a los criterios formales o de apariencia a los que ordinariamente, para la salvaguarda de los derechos de los terceros, ha de atenerse la ponderación de la existencia de responsabilidad ganancial externa por el acto unilateral de un cónyuge.

\section{BIBLIOGRAFÍA}

Abelló Margalef, Ramón, "Notas sobre las cargas y obligaciones de la sociedad de gananciales», $R D P$, n. $^{\circ} 66,1982$, págs. 803-815.

Albaladejo, Manuel, Curso de Derecho civil, IV (Derecho de familia), 5. ${ }^{a}$ ed., José María Bosch Editor, Barcelona, 1991.

Alberruche Díaz-Flores, María Mercedes, «Pactos entre progenitores para distribuir su responsabilidad por los actos de sus hijos», La Ley Derecho de familia, n. ${ }^{\circ}$ 5, 2015, págs. 94-106 [versión digital obrante en laleydigital360 (LA LEY 25/2015)].

Algaba Ros, Silvia, «Los bienes gananciales y su responsabilidad por las deudas tributarias. La modificación del régimen económico matrimonial en perjuicio de sus acreedores. Comentario a la Sentencia del Tribunal Supremo de 21 de junio de 2005 (RJ 2005, 6424)», Revista de Derecho Patrimonial, n. ${ }^{\circ} 17,2006$, págs. 273-283 [versión electrónica (BIB 2006\1080)].

Antunes Varela, João de Matos, Direito da família, Livraria Petrony, Lisboa, 1987. 
ARCERI, Alessandra, I regimi patrimoniali della famiglia in prospettiva europea, Giuffrè Editore, Milán, 2016.

Barceló DomÉNeCH, Javier, Responsabilidad de los bienes gananciales por las obligaciones extracontractuales de un cónyuge, Tirant lo Blanch, Valencia, 2000.

Bello JaneIRo, Domingo, La defensa frente a tercero de los intereses del cónyuge en la sociedad de gananciales, José María Bosch Editor, Barcelona, 1993.

Benavente Moreda, Pilar, Naturaleza de la sociedad de gananciales. Legitimación individual de los cónyuges, Colegio de Registradores de la Propiedad y Mercantiles de España. Centro de Estudios Registrales, Madrid, 1993.

Bustos Moreno, Yolanda B., Las deudas gananciales y sus reintegros, Dykinson, Madrid, 2003.

Cabrillac, Rémy, Droit civil. Les régimes matrimoniaux, $4 .{ }^{\mathrm{a}}$ ed., Montchrestien, París, 2002.

Castán Tobeñas, José, Derecho Civil Español, Común y Foral, T. V (Derecho de familia), Vol. I (Relaciones conyugales), 9. ${ }^{\text {a }}$ ed. (revisada y puesta al día por García Cantero y Castán Vázquez), Reus, Madrid, 1976.

Colomer, André, Droit civil. Régimes matrimoniaux, 4. ${ }^{\mathrm{a}}$ ed., Litec, París, 1990.

CORSI, Francesco, Il regime patrimoniale della famiglia, I (I rapporti patrimoniali tra coniugi in generale. La comunione legale), en CICU y MESSINEO, Trattato di Diritto Civile e Commerciale, Vol. VI-t. I, sez. 1, Dott. A. Giuffrè Editore, Milán, 1979.

De Cossío y Corral, Alfonso, La sociedad de gananciales, en Tratado práctico y crítico de Derecho civil, T. 50, Vol. I, Instituto Nacional de Estudios Jurídicos, Madrid, 1963.

De Diego, Felipe Clemente, Instituciones de Derecho Civil Español, T. II, Imprenta de Juan Pueyo, Madrid, 1930.

De Los Mozos y De los Mozos, José Luis, «Artículo 1.366», en Albaladejo (Dir.), Comentarios al Código Civil y Compilaciones Forales, T. XVIII, Vol. 2. ${ }^{\circ}$ (Artículos. 1.344 a 1.410 del Código Civil), Ed. Revista de Derecho Privado, Madrid, 1984, págs. 290-299.

De PaOla, Vincenzo, y Macri, Antonio, Il nuovo regime patrimoniale della famiglia, Giuffrè Editore, Milán, 1978. 
Díez-Picazo y Ponce de León, Luis, y Gullón Ballesteros, Antonio, Sistema de Derecho Civil, Vol. IV (Derecho de familia. Derecho de sucesiones), Tecnos, Madrid, 1978.

- Sistema de Derecho Civil, Vol. IV (T. I), Derecho de familia, 11. ${ }^{\text {e ed., }}$ Tecnos, Madrid, 2013.

FABAR CARnero, Alberto, "Aproximación al régimen de responsabilidad externa en la sociedad de gananciales», RDUNED, n. ${ }^{\circ} 19$, 2016, págs. 653-690.

FERnández Canales, Carmen, «La responsabilidad derivada del art. 1366 del Código Civil», Práctica Derecho de Daños, n. ${ }^{\circ} 117$, 2013, págs. 6-21 [versión digital obrante en laleydigital360 (LA LEY 8050/2013)].

Galgano, Francesco, Trattato di Diritto Civile, V. I (Le categorie generali. Le persone. La proprietà. La famiglia. Le successioni. La tutela dei diritti), Cedam, Padova, 2009.

Giménez DuART, Tomás, "Cargas y obligaciones del matrimonio», $R D P$, n. $^{\circ} 66,1982$, págs. 542-555.

GÓMEZ DE LA EscaLERA, Carlos Rafael, «Las obligaciones extracontractuales de un cónyuge y el nuevo régimen de responsabilidad de los bienes gananciales», Diario La Ley, n. ${ }^{\circ}$ 1, 1985, págs. 1189-1198 [versión electrónica obrante en laleydigital360 (LA LEY 17952/2001)].

Goubeaux, Gilles, en VoIRIN, Pierre, Droit civil (Droit privé notarial. Régimes matrimoniaux. Successions-Libéralités), T. 2, 22. ${ }^{\text {a }}$ ed., Librairie Générale de Droit et de Jurisprudence, París, 2002.

GuILARTE GutIÉRREZ, Vicente, Gestión y responsabilidad de los bienes gananciales, Lex Nova, Valladolid, 1991.

LaCruz Berdejo, José Luis, en Lacruz y Albaladejo, Derecho de familia. El matrimonio y su economía, Tratado teórico-práctico de Derecho Civil, T. IV, Vol. 1. ', Librería Bosch, Barcelona, 1963.

LACRUZ Berdejo, en Lacruz et al., Elementos de Derecho Civil, IV, Derecho de familia, Vol. I, 3. ${ }^{\text {a }}$ ed., José María Bosch Editor, Barcelona, 1990.

LucET, Frédéric, y VAREILle, Bernard, Droit civil (Régimes matrimoniaux, libéralités, successions), 4. ${ }^{\mathrm{a}}$ ed., Dalloz, París, 2001.

Malaurie, Philippe, y AynÈs, Laurent, Cours de Droit civil. Les régimes matrimoniaux, Éditions Cujas, París, 1988. 
Manresa y Navarro, José María, «Artículo 1410», Comentarios al Código Civil Español, T. IX, 5. ${ }^{\text {e }}$ d. (revisada por Castán Vázquez), Instituto Editorial Reus, Madrid, 1950, págs. 621-628.

Martín BRICEÑo, María del Rosario, «La responsabilidad de los bienes gananciales por las obligaciones extracontractuales de un cónyuge (1)», LA LEY Derecho de familia, n. . 8, 2015 [versión digital obrante en laleydigital360 (LA LEY 5936/2015)].

Martínez Lago, Miguel Ángel, La extensión de la responsabilidad a las sanciones tributarias, Tirant lo Blanch, Valencia, 2008.

Martínez VÁzQuez de CASTRo, Luis, Responsabilidad patrimonial de la sociedad de gananciales, Civitas, Madrid, 1995.

Mosco, Luigi, Diritto di famiglia (Matrimonio-Regime patrimoniale della famiglia-Filiazione legittima e naturale), Dott. Francesco Cacucci Editore, Bari, 1977.

Mucius Scaevola, Q., Código Civil concordado y comentado extensamente, T. XXII (Artículos 1.392 á 1.444), Imprenta de P. Apalategui, Madrid, 1905.

PeÑa Bernaldo de Quirós, Manuel, «Art. 1.366», en PAZ-ARES et al. (Dirs.), Comentario del Código Civil, T. II, Ministerio de Justicia, Madrid, 1991, págs. 697-699.

Pereira Coelho, Francisco, y De Oliveira, Guilherme, Curso de Direito da família, Vol. I (Introdução. Direito matrimonial), 5. a ed., Imprensa da Universidade de Coimbra, Coimbra, 2016.

Pires de Lima, Fernando A., y Antunes Varela, João de Matos, Código Civil anotado, Vol. IV (Artigos $1576 .^{\circ}$ a $1795 .{ }^{\circ}$ ), 2. ${ }^{\mathrm{a}}$ ed., Coimbra Editora, Limitada, 1992.

Puig Peña, Federico, Tratado de Derecho Civil español, T. II (Derecho de familia), Vol. I (Teoría general del matrimonio), Ed. Revista de Derecho Privado, Madrid, 1947.

Ragel SÁnchez, Luis Felipe, El Régimen de Gananciales, Aranzadi, Cizur Menor, 2017.

Rams Albesa, Joaquín José, La sociedad de gananciales, Tecnos, Madrid, 1992.

Reyes Monterreal, José María, El régimen legal de gananciales, Gráficas Menor, Madrid, 1962.

Rueda PÉRez, Manuel Ángel, y Rueda PÉREz, José María, «Notas sobre la nueva regulación de las cargas y obligaciones de la sociedad de 
gananciales tras la reforma del Código Civil de 13 de mayo de 1981 », RDP, n. ${ }^{\circ} 66,1982$, págs. 556-593.

SánCHez Román, Felipe, Estudios de Derecho Civil según los principios, los precedentes y cuerpos legales del antiguo Derecho de Castilla, las leyes civiles generales, las especialidades de las legislaciones forales, la jurisprudencia del Tribunal Supremo de Justicia y el Código Civil

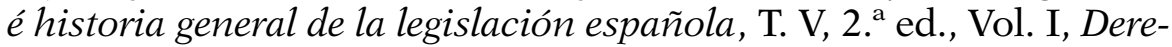
cho de familia, Establecimiento Tipográfico «Sucesores de Rivadeneyra», Madrid, 1898.

TORRAlBa Soriano, Vicente, «Art. 1.366», en AMORÓS GUARDIOLA et al., Comentarios a las reformas del Derecho de familia, Vol. II, Tecnos, Madrid, 1984, págs. 1691-1701.

Valverde y Valverde, Calixto, Tratado de Derecho civil español, T. IV, Parte especial (Derecho de familia), 2. ${ }^{\mathrm{a}}$ ed., Talleres Tipográficos Cuesta, Valladolid, 1921.

Yzouierdo Tolsada, Mariano, «El perturbador artículo 1.092 del Código Civil: cien años de errores», en Centenario del Código Civil (1889-1989), T. II, Ed. Centro de Estudios Ramón Areces, Madrid, 1990, págs. 2109-2135. 